\title{
Evaluating sectoral effects of agricultural nitrogen pollution reduction policy in Croatia within a CGE framework
}

\author{
Ozana Nadoveza Jelić ${ }^{1,2^{*}}$ (D) and Jurica Šimurina ${ }^{1}$
}

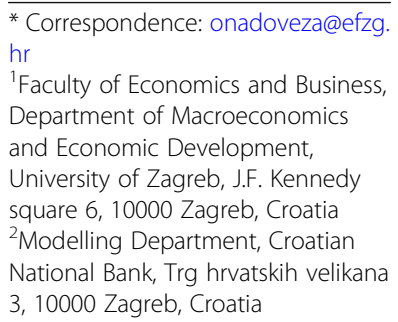

*Correspondence: onadoveza@efzg. hr

${ }^{1}$ Faculty of Economics and Business, Department of Macroeconomics and Economic Development, University of Zagreb, J.F. Kennedy square 6, 10000 Zagreb, Croatia ${ }^{2}$ Modelling Department, Croatian National Bank, Trg hrvatskih velikana 3, 10000 Zagreb, Croatia

\begin{abstract}
Environmental policies are becoming an important part of agricultural policy portfolio in the EU, which is binding on Croatia. This paper seeks to evaluate potential sectoral effects of several nitrogen pollution reduction policy measures within CGE model for Croatia. Finding appropriate agri-environmental policy design represents a typical optimization problem. Thus, the paper attempts to find potential agri-environmental measures which comply with supranational directives without jeopardizing other economic policy goals. Results show that polluter-pays principlebased measures, if not accompanied by the provider-gets principle measures, could have relatively large negative economy-wide effects in Croatia. However, these effects can be reduced by the appropriate policy mix.
\end{abstract}

Keywords: Agriculture, Agri-environmental policy, Small open economy, Croatia, Nitrogen pollution, Sectoral effects

\section{Introduction}

Recent study by Rockström et al. (2009) showed that reactive nitrogen creation surpassed its "planetary boundary" substantially. According to Rockström et al. (2009), nitrogen cycle is one of the nine planet's biophysical processes and subsystems which are associated with Earth system stability and its creation has surpassed the proposed planetary boundary almost by the factor of three. Due to interlinks among various Earth (sub) systems and processes, crossing one safe threshold could be more dangerous than it may seem at first. Namely, crossing one safe threshold can speed up the transgression of other Earth-system processes and thus have "disastrous consequences for humanity" (Rockström et al. 2009).

These alarming trends stimulated researchers' interests for excessive reactive nitrogen creation causes and its adverse environmental and human health consequences. Most of the studies during the 1990's (e.g. Oenema et al. 1997; Dise et al. 1998; Refsgaard et al. 1999 etc.) were concentrated on different calculation methods for nitrate leaching loss in runoff estimation and nitrous oxide emissions estimates, with just a few papers dealing with potential large-scale adverse consequences. However, by the end of 1990's, and especially during the first decade of 2000's, comprehensive research of potential large-scale adverse consequences of excessive nitrogen creation defined widely recognized nitrogen emission costs which include: i) human health risks due to

(c) The Author(s). 2020 Open Access This article is distributed under the terms of the Creative Commons Attribution 4.0 International License (http://creativecommons.org/licenses/by/4.0/), which permits unrestricted use, distribution, and reproduction in any medium, provided you give appropriate credit to the original author(s) and the source, provide a link to the Creative Commons license, and indicate if changes were made. 
polluted drinking water and high concentration of nitrogen dioxide in the air (induces respiratory issues, cancer, and cardio problems), ii) eco-system costs (i.e. negative effects on biodiversity - through acidification, eutrophication and habitat degradation) and iii) climate change and ozone depletion risks (e.g. Millennium Ecosystem Assessment 2005; Rockström et al. 2009; Science for Environment Policy 2013 etc).

To slow down environmental and climate pressures as well as health related risks of reactive nitrogen creation the EU identified emissions resulting from agricultural activities as one of the four major areas of action in its environmental action program (European Environment Agency 2006). However, the EU efforts did not result in an increase of comprehensive research tackling the efficiency and potential economic (Oenema et al. 2009) and sectoral effects of such policies in its member states.

As an EU member state, Croatia has the obligation to implement supranational agrienvironmental policies which will become an even more important part of the Common agricultural policy (CAP) framework. Due to its potential economy-wide (side) effects it is important to anticipate potential sectoral effects of nitrogen pollution reduction policies. Therefore, this research seeks to evaluate potential sectoral effects of several nitrogen pollution reduction policy measures in Croatia. Analysis of sectoral effects of agricultural nitrogen pollution reduction measures includes two sets of potential policies, i.e. market-based and regulatory policy measures. Market-based measures are formed as polluter-pays (taxes-based), provider-gets (subsidy-based) and combined policy instruments. The evaluation is carried out within standard CGE model in the presence of pollution disutility, agricultural amenities and labor market imperfections. Since CGE models can offer coherent and consistent answers to the questions on economic impacts of changes in tax rates or of the introduction of new taxes or subsidies (Conrad 2001) they are a suitable tool for alternative nitrogen reduction policies rankings. Thus, the paper seeks to find potential agricultural nitrogen pollution reduction measures which are able to comply with supranational directives without compromising other economic policy goals.

The paper is structured as follows. Second part provides a brief presentation of nitrogen pollution trends and policies within the EU with an emphasis on Croatia. Methodology and database development are presented in the third part of the paper. Fourth part presents simulated sectoral effects of selected nitrogen reduction agrienvironmental policies in Croatia. Finally, the fifth part concludes and highlights policy implications of the results.

\section{Nitrogen pollution trends and reduction policies in the EU Nitrogen pollution trends in the EU member states}

Most studies suggest that overproduction of reactive nitrogen forms will spread throughout the world by 2050. Reactive nitrogen creation spatial patterns point to a significant contribution of the European Union in the 1990s. Although reactive nitrogen flows creation is decreasing in most EU member states, the EU is still an aboveaverage contributor to nitrogen pollution at the global scale (Galloway et al. 2004; Millennium Ecosystem Assessment 2005; Science for Environment Policy 2013).

One of the most important available indicators of agricultural nitrogen pollution in the EU is a set of indicators included in Gross Nitrogen Balance dataset. The main 
indicator within Eurostat database is represented by the gross nitrogen surplus per hectare of utilized agricultural area (UAA) which is calculated as the "total gross nitrogen surplus divided by the reference area. The indicator provides an indication of the potential surplus of nitrogen $(\mathrm{N})$ on agricultural land (kg N per ha per year)" (Eurostat 2012). Nitrogen pollution and nitrogen cycle perturbation risks are greater the higher the value of the gross nitrogen surplus per hectare of UAA. To illustrate potential risks at the EU level, Fig. 1 provides a comparative overview of an average gross nutrient balance per hectare of UAA ( $\mathrm{kg}$ of nitrogen per ha) in all EU member states, Norway and Switzerland for two five-years sub-periods, i.e. from 2000 to 2004 and from 2010 to 2014.

Figure 1 shows that the average nitrogen surplus stood at about $65 \mathrm{~kg}$ of nitrogen per hectare of UAA in 2014. The lowest nitrogen surplus was recorded in Romania during both analyzed periods (on average 9 and $1 \mathrm{~kg}$ of nitrogen per hectare of UAA in the period 2000-2004 and 2010-2014 respectively). The highest nitrogen surplus was documented in Malta (247 kg of nitrogen per hectare UAA in the period 2000-2004) and Cyprus (189 kg of nitrogen per hectare of UAA in the period 2010-2014). With an average nitrogen surplus of 117 (2000-2004) and 75 (2010-2014) kilograms of nitrogen per hectare of UAA Croatia is ranked similar to highly developed countries such as Germany, Norway and Luxembourg. Since, in line with global patterns, less developed countries (the new EU member states) usually have lower nitrogen surplus, current trends reveal that Croatia's nitrogen surplus situation is worrisome.

Although the data in Fig. 1 are encouraging (i.e. trends show a general reduction of nitrogen surplus at the aggregate and country level within the EU), the degree of agricultural nitrogen pollution in the EU is still significant. However, positive trends may indicate that the nitrogen pollution reduction directives and policies described in the next sub-section generated favorable changes.

Since the excess nitrogen land content represents the difference between total nitrogen inputs and total nitrogen outputs, the nitrogen usage efficiency is the greatest contributor to excess nitrogen creation. Efficiency ratios, calculated as the ratio of nitrogen outputs and nitrogen inputs, are presented in Fig. 2. Higher levels of nitrogen use

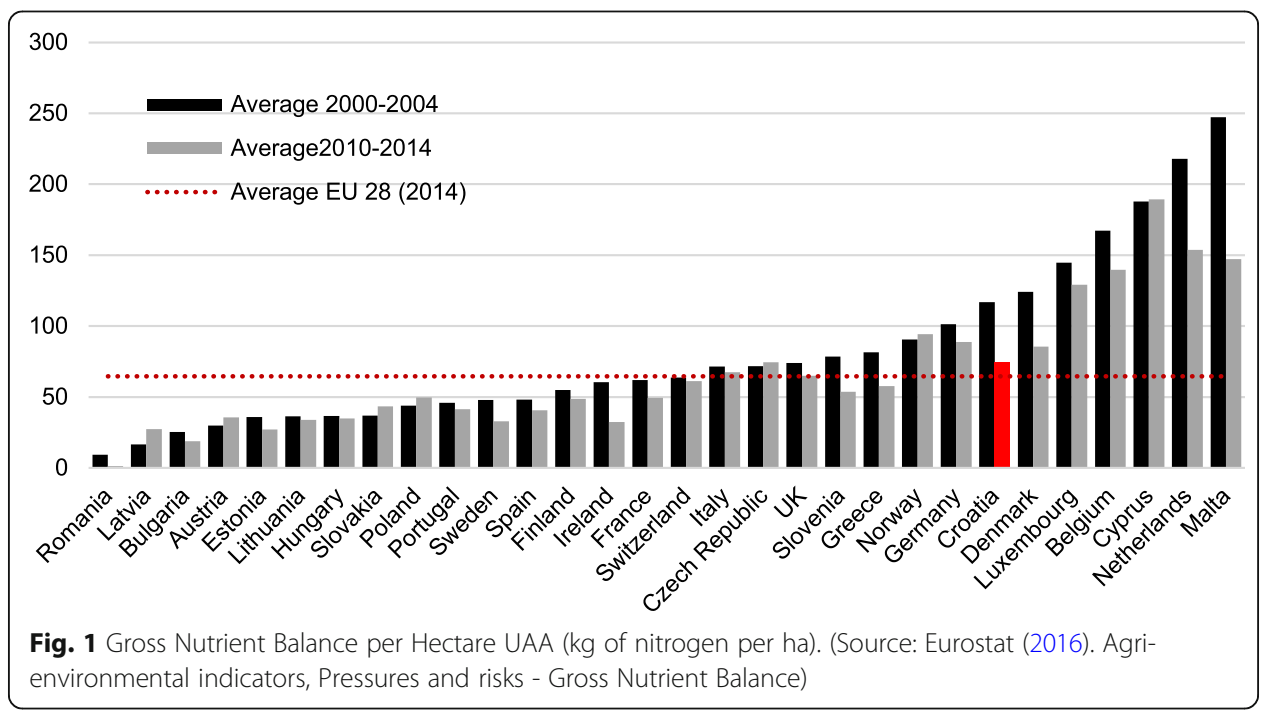




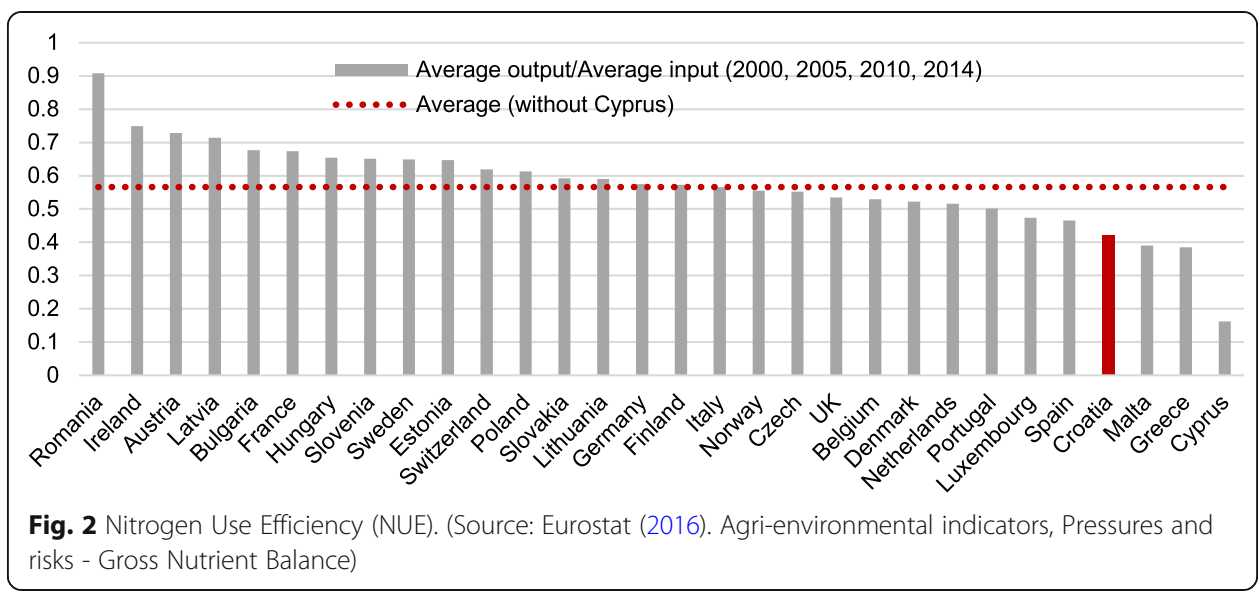

efficiency (NUE) ratios indicate greater relative utilization of nitrogen. Trends shown in Fig. 2 reveal that countries with higher nitrogen surpluses are usually the most inefficient users of nitrogen.

The data presented in Fig. 2 suggest above-average nitrogen pollution potential in Croatia. More precisely, Croatia ranks as the fourth worst EU member state. Low NUE in Croatia is a result of both above-average inputs and below-average nitrogen outputs per hectare of UAA. Although Croatia has reduced its total consumption of nitrogenbased mineral fertilizers in the last 15 years, and despite positive trends in the reduction of the gross nitrogen balance over the same period, it should be emphasized that this decline occurred simultaneously with the severe decrease of agricultural production. Nitrogen use efficiency (NUE) could be improved by decreasing nitrogen inputs or increasing nitrogen outputs. Both components of NUE are partially determined by natural processes and characteristics. Since it is almost impossible to affect most of them, it is important to decrease significant nitrogen inputs which are relatively easy to control.

Figure 3 depicts the average shares of certain types of nitrogen inputs in total nitrogen inputs during 2010-2014 period. Data confirms the dominance of inorganic (nitrogenous) fertilizers in the total nitrogen input at the EU level whereas its share exceeds $45 \%$. The lowest average share was recorded in Cyprus (16\%), and the highest in Bulgaria (61\%). In Croatia, this share stands at $52 \%$, which is above the EU average.

\section{Agri-environmental policies in the EU member states}

Farmers usually pay a low price for using the environment. Heterogeneity of agricultural landscapes makes the environmental issues especially pronounced in agriculture and some authors suggest that the solution may necessitate the use of non-uniform instruments (Lankoski et al. 2010) which are far more complicated to conduct and enforce than uniform solutions. To deal with these problems, the EU has launched several legal initiatives aimed at reducing agricultural nitrogen pollution, among which Nitrates Directive (adopted in 1991) stands out as the most important.

The Nitrates Directive defines Nitrate vulnerable zones (NVZs) and establishes Code(s) of Good Agricultural Practice(s) and Action Programs. The latter are 


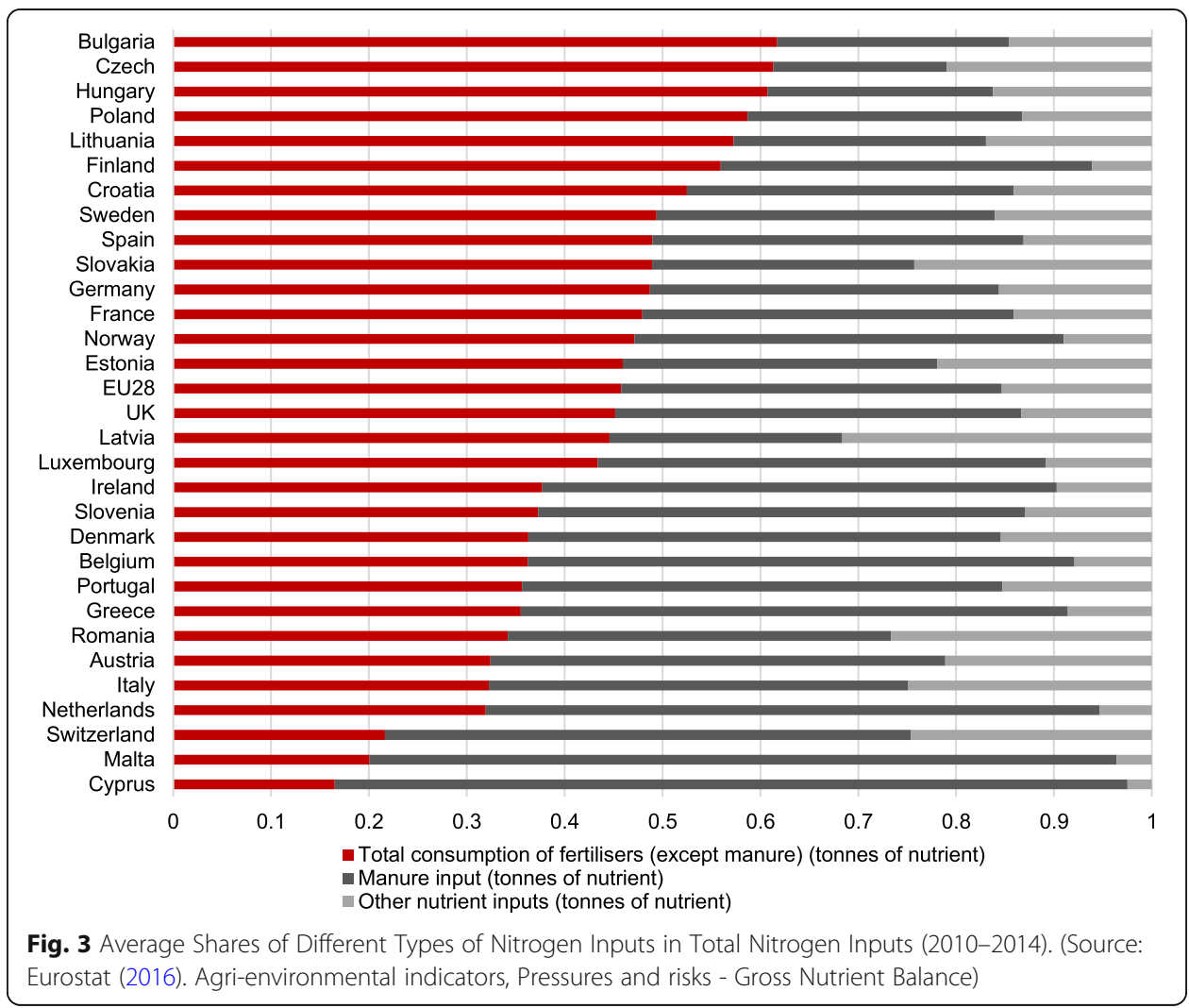

mandatory for farmers in NVZs, while the former are implemented on a voluntary basis. Water Framework Directive is another legislative framework at European Union level compatible with the Nitrates Directive. The text of the Directive contains an indicative list of pollutants that, inter alia, include compounds and substances contributing to eutrophication (especially nitrates and phosphates). The proposed measures aim to reduce the flow of nutrients (such as nitrogen and phosphorus) to ground and surface water and include measures aimed at reducing the input of these nutrients. The legislative framework also proposes changes to farming fertilizers application techniques, as well as preventive measures to avoid soil erosion (European Parliament and European Council 2000). Along with the accession into the EU Croatia committed to comply with the EU legislation. Croatia passed the Code of Good Agricultural Practices in 2008 which became effective in 2013. The Code of Good Agricultural Practices in fertilizers application has put limitations on the application of fertilizers to land, i.e. $210 \mathrm{~kg} \mathrm{~N} / \mathrm{ha}$ for the first four years of the Action Programme (2013-2017) and $170 \mathrm{~kg} \mathrm{~N} / \mathrm{ha}$ afterwards.

Beside regulations-based agri-environmental policy measures embodied in Nitrates Directive, the CAP framework includes a range of market-based instruments for environmental purposes (e.g. taxes, charges, tradable permit schemes and subsidies). According to the official website of the European Commission the integration of environmental concerns into the CAP reflects the two principles, the "polluter pays principle" and the "provider gets principle". Polluter pays principle implies that the polluter should bear the costs of environmental damage. This principle is usually enforced through taxes, charges and tradable permits. On the other side, "provider gets 
principle" is taken up via agri-environment payments, such as subsidies, which cover the costs incurred by environmental commitments.

Despite extensive legislative and policy frameworks, Fig. 4 suggests that in 2015 internalization of agricultural pollution social costs was not achieved at the EU level. Namely, internalization of the agricultural emissions requires that the contribution of agriculture, which is an above-average polluter, to total environmental taxes (and in particular pollution taxes) exceeds the gross value-added contribution of agriculture. However, in most EU countries this is not the case. For example, in Spain, the share of agriculture in gross value added stands at $2.5 \%$, while agriculture's contribution to total environmental taxes reaches only $1 \%$, whereas agriculture is not accounted for in pollution taxes. A similar situation is present in most EU countries. In Croatia agricultural value-added contribution of around 4\% matches non-existent agricultural contribution to pollution taxes in 2015. The most obvious exceptions are Denmark and Sweden where low contribution of agriculture to the gross value added is accompanied by a relatively high agricultural contribution to environmental and pollution taxes.

To illustrate the potential of pollution taxes in reducing agricultural nitrogen pollution a scatterplot of agricultural pollution (measured by gross nitrogen balance) and pollution taxation is shown in Fig. 5. The diagram on the left-hand side of the Fig. 5 shows the individual data for all EU countries. It is difficult to see any regularities and potential correlation between the two indicators. Namely, pollution taxes are nonexistent in several EU countries, while few countries have exceptionally high pollution taxes. Due to these outliers and differences in some exogenously given natural characteristics that lead to very diverse nitrogen surpluses (regardless of employed taxes), it is impossible to draw any conclusions. However, after excluding outliers and zeros (no taxes) we can see the expected negative relationship between pollution taxation and agricultural nitrogen pollution on the right-hand side diagram of Fig. 5. Although right-hand side diagram of Fig. 5 supports the idea that taxes might be an efficient policy tool for reduction of agricultural nitrogen pollution, it should be interpreted with caution. The figure only indicates that there seems to exists a negative correlation

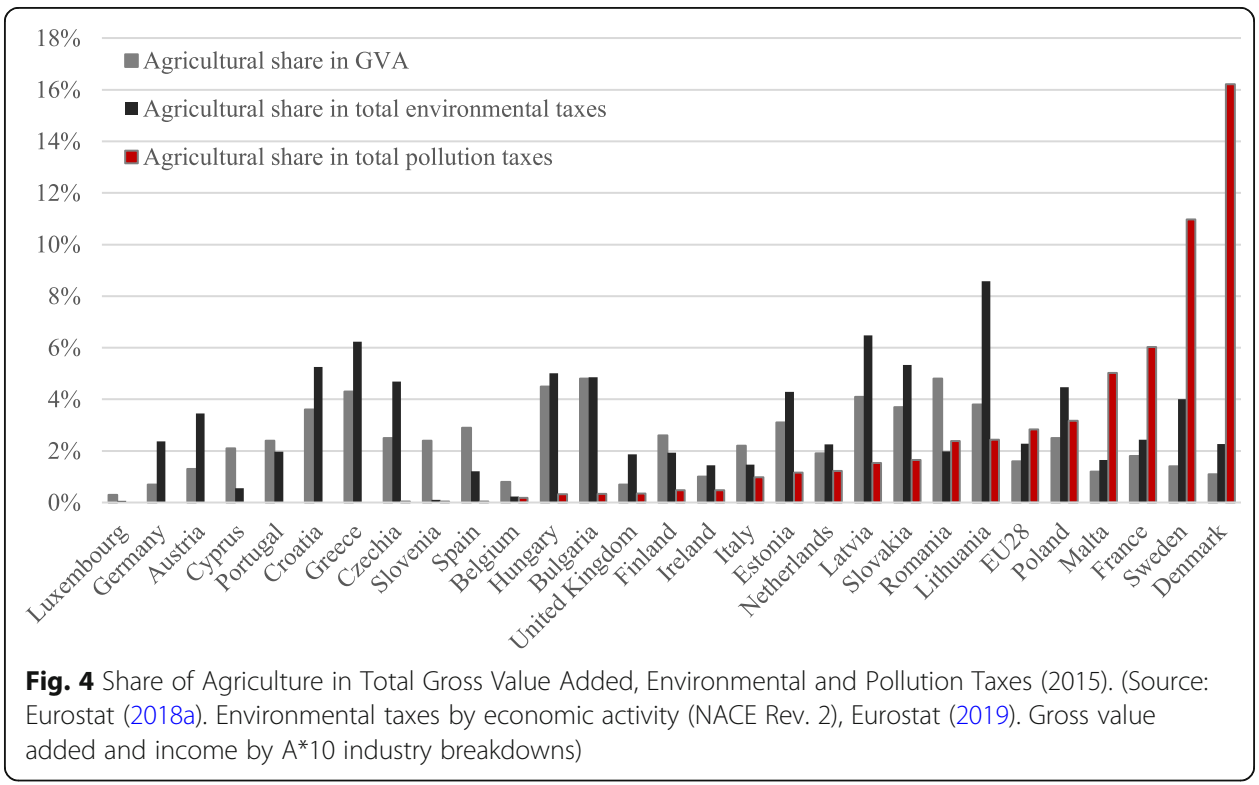



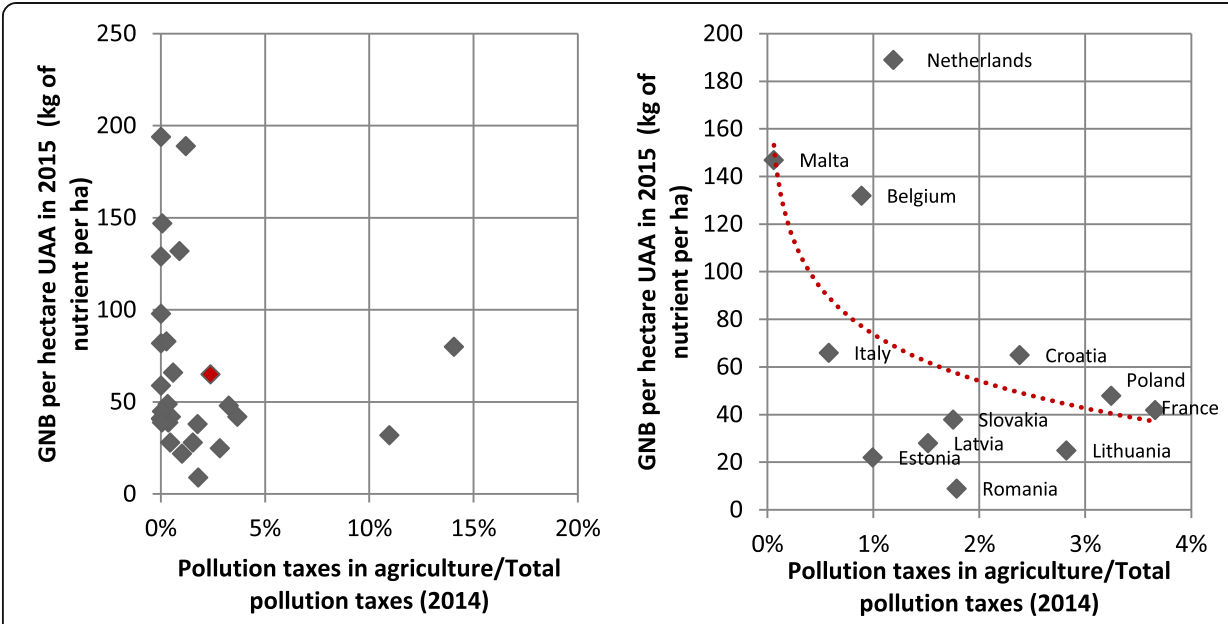

Fig. 5 GNB (2015) vs Environmental Taxes on Agricultural Pollution (2014). (Source: Eurostat (2018b) Agrienvironmental indicators, Pressures and risks - Gross Nutrient Balance, Eurostat (2018a). Environmental taxes by economic activity (NACE Rev. 2))

between pollution taxes and agricultural nitrogen pollution, which does not imply causation.

\section{Methodology and data Methodology}

To correct market failure induced by agricultural externalities government can select among alternative market-based and regulatory (command-and-control) measures. Our analysis includes measures from both sets of potential policies. Market-based measures are formed as polluter-pays (taxes-based), provider-gets (subsidy-based) and combined policy instruments Our alternative measures selection is based on the previous research such as Kampas and White (2004), Peterson et al. (2002), Taheripour et al. (2008), Vermersch et al. (1993) etc. These include: i) tax on polluting good, ii) government revenue neutral tax on polluting good, iii) tax on use of nitrogen fertilizers in agricultural production, iv) government revenue neutral tax on use of nitrogen fertilizer in agricultural production, v) combination of a subsidy for benefits provided by agriculture and a tax on use of nitrogen fertilizers in agriculture, vi) government revenue neutral subsidy for benefits provided by agriculture. Analysis of regulatory agri-environmental policies includes the following measures: i) quantitative requests to decrease the use of mineral fertilizers in agriculture and ii) quantitative requests to increase the land use in agricultural production.

We use standard CGE modeling technique to evaluate the economy-wide effects of agricultural nitrogen pollution measures in the presence of pollution disutility, agricultural amenities and labor market imperfections. CGE models are suitable for alternative policies rankings and are able to offer coherent and consistent answers to questions of economic impacts to changes in the tax rates or introduction of a new taxes or subsidies (Conrad 2001). Beside general equilibrium based evaluations, few papers in the research area use partial equilibrium approach (e.g. Lankoski and Ollikainen 2003; Peterson et al. 2002). However, we find general equilibrium approach to be the more 
appropriate tool for sector-level evaluation purposes due to tight links between agriculture and other sectors in the economy.

Methodology and assumptions in this research are largely inspired by the work of Kristkova and Ratinger (2013), Lankoski and Ollikainen (1999, 2003), Parry (1999, 1997), Peterson et al. (2002) and Taheripour et al. (2008). However, most of the research in the area of the agricultural nitrogen pollution reduction addresses agrienvironmental policy issues in the context of large open economies and wellfunctioning labor markets. This research extends the previous studies by employing several market imperfections (multifunctional agriculture, unemployment and immobility of agricultural labor) and small open economy assumption. Additionally, to our knowledge, this study is a rare example of an analysis in the field which focuses on sectoral effects of agri-environmental policies.

Generally, CGE modeling framework is less frequently used in agri-environmental policy research than in the industrial carbon reduction policy studies (see FreireGonzález 2018). This is mostly due to data and environmental effects modeling limitations (OECD 2012) as well as some agricultural sector characteristics (non-point source polluter characterized by heterogeneity and uncertainty). Additional limitations of the analysis include uncertainty over assumed predetermined parameters of the model, as well as comparative-static nature of the analysis. Still, at this relatively high level of aggregation and in accordance with the (economy-wide sector-level) objectives of this study, none of the limitations should reverse the findings and conclusions for policy purposes.

Since the lack of suitable data and agricultural nitrogen losses and environmental response functions limit the possibility of more disaggregated CGE based evaluation, CGE model for Croatia considers seven aggregated sectors according to statistical classification of products (CPA) with the following scope: 1) sector A which includes agricultural, food, beverage and tobacco products: 2 ) sector BC which includes mining and quarrying and resource based manufactured products including chemicals and chemical products; 3 ) sector $C$ which includes manufactured products not included in the previous sectors; 4) sector DG which is composed of energy, water, construction and trade products and services; 5) sector $\mathrm{HJ}$ which consists of transportation, information and accommodation and food services; 6) sector KN which is composed of financial, real estate, professional and administrative services; 7) sector OU which includes public, education, health, social and other services.

It is assumed that the agricultural sector (A) produces two externalities, i.e. "public bad" and "public good". It generates "public bad" which results in nitrogen pollution. It is assumed that the nitrogen pollution stems from demand of agriculture for $\mathrm{BC}$ sector goods which contains chemical industry products. Therefore, we use agricultural intermediate demand for chemical industry products as the proxy for nitrogen compounds usage in agriculture. We assume that nitrogen is substitutable in agricultural production. On the other hand, agriculture provides "public goods" (environmental benefits)which are usually associated with landscape amenities resulting from land cultivation (OECD 2001). Even though the multifunctional agriculture concept has been documented in literature for more than fifteen years, this non-internalized agricultural "public good" is not always recognized as a potentially important factor in agrienvironmental policies evaluation. However, in line with EU trends and "provider-gets" 
principle, we find it suitable to consider multifunctional agriculture assumption when analyzing alternative agri-environmental policies. Both environmental externalities are modeled in a very simplistic fashion. As already mentioned, agriculture is a diffuse and heterogenic polluter and multifunctionality of agriculture is a much wider concept then just the provision of landscape amenities. Still, unavailability of data hampered more complex and disaggregate CGE based analysis at this point, at least in the case of Croatia.

The model follows standard CGE modeling framework (see Appendix for detailed derivation of the model) except for labor market cleaning conditions and agricultural pollution and amenities extensions (see eqs. 8-9 and 62-65 in Appendix). Here, we present only the equations which are relevant for the agri-environment policy assessment, i.e. the equations in which the policy change is introduced. All market-based measures affect government revenues $(T R)$ given by:

$$
T R=t_{Y} Y+\sum_{i=1}^{7}\left(t c_{i} P_{i} C_{i}\right)+t k_{i} K_{i} P_{K}+t l_{i} L_{i} P_{L}+\sum_{i=1}^{7} \sum_{j=1}^{7} i o_{j, i} X D_{i} P_{j} t i m_{i}, i=j
$$

Where $i$ and $j$ represent sectors, $Y$ stands for income, $t_{Y}$ is income tax, $t c_{i}$ are consumption taxes, $P_{i}$ are prices of final goods and $C_{i}$ is consumption. $P_{L}$ and $P_{K}$ represent labor and capital prices, while $t l_{i}$ and $t k_{i}$ represent labor and capital taxes respectively. $K_{i}$ and $L_{i}$ represent capital and labor. Matrix of technical coefficients is represented by $i o_{n i, i}$, while $X D_{i}$ stands for domestic goods supply and $t_{i m}$. for intermediate inputs taxes.

\section{Market-based measures}

1. Polluter-pays principle measures

i) Tax on polluting $\operatorname{good}\left(t c_{A}\right)$

When introducing a tax on polluting good, government effectively increases current taxes in agricultural sector $\left(t c_{A}\right)$ by some factor. This immediately affects the consumer demand/consumption $\left(C_{i}\right)$ as it is clear from eq. (2).

$$
C_{i}=\left[\left(1+t c_{i}\right) P_{i} \mu_{i}+\alpha_{i} P_{i}\left(\left(1-t_{Y}\right) Y-S_{H^{-}} \sum_{i=1}^{7}\left(1+t c_{i}\right) P_{i} \mu_{i}\right)\right] /\left[\left(1+t c_{i}\right) P_{i}\right]
$$

In (2) $S_{\mathrm{H}}$ stands for household savings, $\mu_{i}$ denotes subsistence consumption level and $\alpha_{i}$ 's are the parameters of consumer utility function represented by Stone-Geary linear system of expenditures. As before $Y$ stands for income, $t_{Y}$ is income tax, $t c_{i}$ are consumption tax rates, $P_{i}$ are prices of final goods and $C_{i}$ is consumption. This policy also affects consumer prices and unemployment rate due to its effects on real wages.

ii) Government revenue neutral tax on polluting good (neutralization based on decrease of labor tax burden ( $\left.t c_{A_{-}} L U\right)$ and income tax $\left(t c_{A_{-}} Y U\right)$ )

In the case of government revenue neutral tax on polluting good, increased taxes on polluting good $\left(t c_{A}\right)$ are accompanied by lower labor $\left(t l_{i}\right.$ in equation (3)) or income taxes $\left(t_{Y}\right.$ in equation (4)). Lower labor taxes affect labor demand $\left(L_{i}\right)$ and labor market 
equilibrium, while lower income taxes increase disposable income (CBUD) of consumers.

$$
\begin{aligned}
L_{i}= & \left(\frac{K L_{i}}{a F 3 a_{i}}\right) \\
& \left\{\left(1-\gamma 3^{V A_{i}}\right)^{\sigma 3_{V A_{i}}}\left(1+t l_{i}\right) P_{L}^{-\sigma 3_{V A_{i}}}\left[\left(\gamma 3^{V A_{i}}\right)^{\sigma 3_{V A_{i}}}\left(1+t k_{i}\right) P_{K}^{1-\sigma 3_{V A_{i}}}+\left(1-\gamma 3^{V A_{i}}\right)^{\sigma 3_{V A_{i}}}\left(1+t l_{i}\right) P_{L}^{1-\sigma 3_{V A_{i}}}\right]^{\left.\frac{\sigma 3_{V A_{i}}}{\left(1-\sigma 3_{V A_{i}}\right.}\right)}\right\}
\end{aligned}
$$

$$
C B U D=\left(1-t_{Y}\right) Y-S_{H}
$$

In equation (3) $K L_{i}$ is the demand for labor and capital bundle of the $i$-th producer, $\gamma$ $3^{V A_{i}}$ is the distribution parameter of capital in CES production function while $P_{L}$ and $P_{K}$ represent labor and capital prices. Parameter $a F 3 a_{i}$ is a shift parameter. $\sigma 3_{V A_{i}}=1 /(1$ $+\rho 3_{V A_{i}}$ ) represents elasticity of substitution, while $t l_{i}$ and $t k_{i}$ represent labor and capital taxes respectively. In (4) $Y$ stands for income, $t_{Y}$ is income tax, and $S_{H}$ are household savings. These policies change the general equilibrium through many channels but are mainly transmitted through labor market equilibrium and disposable income changes.

iii) Tax on use of nitrogen fertilizers (products of chemical industry) in agricultural production $\left(t B_{A}\right)$

When government introduces taxes on use of nitrogen fertilizers in agricultural sector $\left(t B_{A}\right)$ it immediately affects the agricultural producer's demand/consumption of nitrogen fertilizers $\left(B_{i}\right)$ as evident from equation (5):

$$
B_{i}=\frac{Z B_{i}}{a F 3 b_{i}}\left[\frac{\left(1-\alpha 3_{i}\right)}{\alpha 3_{i}} \frac{P_{Z}\left(1+s Z_{A}\right)}{P_{i=B C}\left(1+t B_{A}\right)}\right]^{\alpha 3_{i}}
$$

Where $P_{Z}$ and $P_{i=B C}$ represent land and BC sector goods prices. Parameter $a F 3 b_{i}$ is a shift parameter, while parameter $\alpha 3_{i}<1$ defines a share of land in the demand for land and $\mathrm{BC}$ sector goods bundle of the $i$-th producer $\left(Z B_{i}\right) . s Z_{A}$ are agricultural amenities subsidies which are set to zero in the initial equilibrium. This policy changes general equilibrium through the agricultural sector intermediate demand and its effects on sectoral production which affects factor markets.

iv) Government revenue neutral tax on use of nitrogen fertilizer (product of chemical industry) in agricultural production (neutralization based on decrease of labor tax burden $\left(t B_{A_{-}} L U\right)$ and income tax $\left.\left(t B_{A_{-}} Y U\right)\right)$

The policy transmitting mechanisms of this measure are similar to the government revenue neutral tax on polluting good. The only difference is that, unlike in ii) where government increases taxes on agricultural (polluting) good, in this case nitrogen reduction policy implies higher nitrogen fertilizer taxes. 
2. Combined polluter-pays and provider-gets principle measure

v) Combination of a subsidy for benefits provided by agriculture and a tax on use of nitrogen fertilizers (product of chemical industry) in agriculture $\left(s Z_{A_{-}} t B_{A}\right)$

When introducing a tax on use of nitrogen fertilizers, government also introduces a subsidy for agricultural amenities $\left(s Z_{A}\right)$. This policy affects the agricultural producer's demand for nitrogen fertilizers $\left(B_{i}\right)$ as shown in (5) and producer's demand for land $\left(Z_{i}\right)$ determined by equation (6).

$$
Z_{i}=\frac{Z B_{i}}{a F 3 b_{i}}\left[\frac{\alpha 3_{i}}{\left(1-\alpha 3_{i}\right)} \frac{P_{i=B C}}{\left(1+s Z_{i=A}\right) P_{Z}}\right]^{\left(1-\alpha 3_{i}\right)}
$$

In equation (6) $P_{Z}$ and $P_{i=B C}$ represent land and $\mathrm{BC}$ sector goods prices. Parameter $a F 3 b_{i}$ is a shift parameter, while parameter $\alpha 3_{i}<1$ defines a share of land in the demand for land and $\mathrm{BC}$ sector goods bundle of the $i$-th producer $\left(Z B_{i}\right)$. The mechanisms through which this policy affects the general equilibrium are partly defined by tax on use of nitrogen fertilizers in agricultural production. However, since higher nitrogen taxes are followed by the land subsidies, agricultural producers are encouraged to substitute nitrogen with land. Newly acquired land can then be used for nitrogen cover crops.

3. Provider-gets principle measure

vi) Government revenue neutral subsidy for benefits provided by agriculture (neutralization based on consumption tax change $\left(s Z_{A_{-}} C U\right)$ )

The policy transmitting mechanisms of government revenue neutral subsidy for benefits provided by agriculture (neutralization based on consumption tax rates change) are defined by (2) and (6). However, this policy assumes change of consumption tax rates on products of all sectors while policy $i$ ) implies higher consumer taxes only for the agricultural sector products. The primary goal of this policy measure is agricultural land expansion. However, due to insufficient incentives to reduce nitrogen usage in agriculture, this combination could fail to reach agricultural nitrogen pollution reduction goals.

\section{Regulatory measures}

vii) Quantitative requests to decrease the use of mineral fertilizers in agriculture $\left(\max B_{A}\right)$

Quantitative requests to decrease the use of mineral fertilizers in agriculture are simply introduced by exogenously setting mineral fertilizers in agricultural production on the level defined by nitrogen pollution reduction policy goals (i.e. $B_{A}=\max B_{A}$ ). The measure affects agricultural producers' decision-making process which is transmitted to other sectors. The sector which produces mineral fertilizers is directly affected. 
Quantitative requests to increase the land use in agricultural production are simply introduced by exogenously setting land in agricultural production on the level defined by policy goals (i.e. $Z_{A}=m i n Z_{A}$ ).

All policies induce a sequence of events which can diversely affect different sectors. Hence, before the implementation of any specific policy, economy-wide sectoral effects should be thought thoroughly to minimize potential adverse impacts of implemented agri-environmental measures.

\section{Data}

We use the data from the input-output tables available at Croatian Bureau of Statistics (CBS 2015). From the input-output tables and other data available at the Croatian Bureau of Statistics, Croatian Ministry of Finance, Croatian National Bank and Croatian Financial Agency, we constructed the social accounting matrix (SAM). Even though SAM is mostly based on the input-output tables, there are data which must be collected from other sources. Data imputed into the SAM sometimes differ from realized and published values/data. This is due to the properties of the SAM. Specifically, the SAM is a quadratic matrix where the sum of values of elements of respective rows and columns must be equal. Data from different sources usually do not satisfy this condition. Table 1 presents the SAM matrix for Croatia in 2010.

Tables 2 and 3 contain the values of the predetermined parameters. Consumer related predetermined parameters include income elasticity of consumption, Frisch parameter, marginal costs and benefits of multifunctional agriculture and unemployment benefits share in labor income (wage). From Table 2 we can see that the lowest income elasticity is assumed for agricultural products, while the highest is in the service sector.

To estimate subsistence consumption level, it is necessary to know value of the Frisch parameter (Table 3) and income elasticity (Table 2). The Frisch parameter establishes a relationship between own-price and income elasticities (Nganou 2005). This parameter is computed from Muhammad et al. (2011) and is defined as a sensitivity of the marginal utility of income to income/total expenditures. Marginal costs of agricultural nitrogen pollution are approximated using Brink et al. (2011), while marginal benefits of multifunctional agriculture (environmental benefits) are approximated as a mean estimate of willingness to pay for environment published in Ciaian and y Paloma (2011) at the EU level (see 7 in Appendix). Level of nitrogen pollution in agriculture $\left(E_{N}\right)$ is approximated by the gross nitrogen surplus (Eurostat 2018b). Share of chemical industry input in total demand of agriculture for products of the BC sector $\left(N O x S H A R E_{A}\right)$ is simply calculated from the Croatian input-output tables (see 8 and 9 in Appendix).

Unemployment benefits $(z)$, are set at the value of a share of labor income and are calculated as a share of the average monetary compensation in 2010 (Croatian Employment Service 2011) in the average monthly net wage for 2010 (Croatian Bureau of Statistics 2010). Values of all mentioned variables are presented in Table 3.

Relation between prices and unemployment are taken from Blanchflower (2001). Blanchflower (2001) estimates this parameter to be between - 0.3 and -0.1 in countries that share some common characteristics with Croatia. Given that Botrić (2012), Družić et al. (2006), Krznar (2011), Šergo et al. (2012) could not prove the existence of the Phillips relationship for Croatia we assumed the lowest estimated value of the 


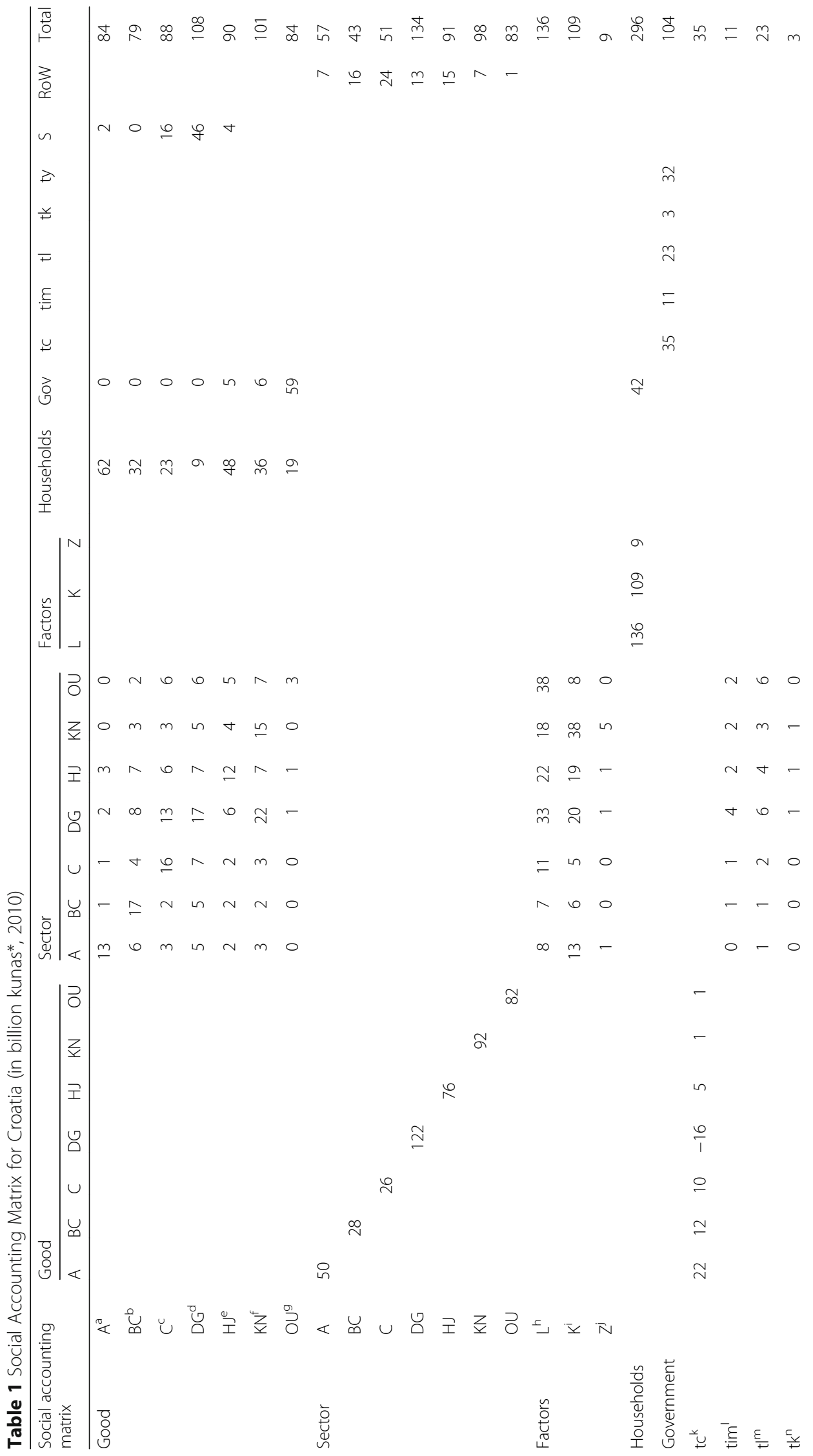




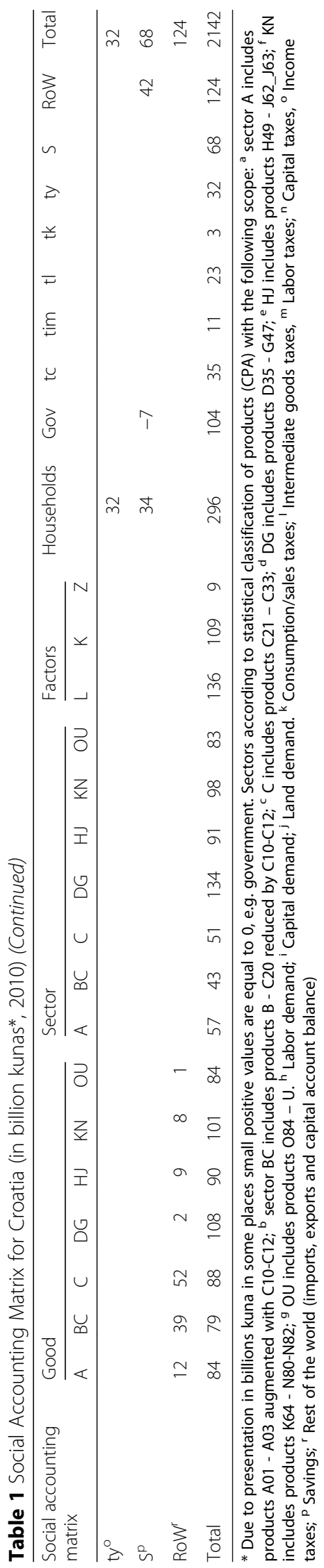


Table 2 Predetermined parameters by sector

\begin{tabular}{lllll}
\hline Sector & Income elasticity & $\sigma 3 \mathrm{VA}_{i}{ }^{a}$ & $\sigma_{T_{i}}{ }^{b}$ & $\sigma_{A_{i}}{ }^{c}$ \\
\hline A & 0.63 & 0.66 & -5.6 & 2.8 \\
BC & 0.97 & 1.06 & -7.1 & 3.56 \\
C & 1.05 & 1.26 & -7.5 & 3.75 \\
DG & 1.28 & 1.63 & -4 & 2.01 \\
HJ & 1.15 & 1.58 & -3.8 & 1.9 \\
KN & 1.07 & 1.26 & -3.8 & 1.9 \\
OU & 1.19 & 1.26 & -3.8 & 1.9 \\
\hline
\end{tabular}

${ }^{\mathrm{a}}$ Elasticity of substitution between capital and labor; ${ }^{\mathrm{b}}$ Export transformation elasticity; ${ }^{\mathrm{c}}$ Elasticity of substitution between domestic and imported goods

parameter, i.e. -0.1 which suggests relatively weak sensitivity of changes in prices to changes in unemployment. Robustness of the results was tested assuming the wage curve, however it did not influence the results significantly.

Other predetermined parameters include elasticities of substitution of capital and labor in a CES production function, elasticities of transformation in CET function and elasticities of substitution in the Armington function. Elasticities are calculated as a weighted averages of the corresponding GTAP values taken from Hertel et al. (2014). Given that the GTAP sectors differ from the CPA sector classification we firstly had to match GTAP sectors with appropriate CPA sectors. After matching, parameters were calculated as weighted averages of the GTAP parameters according to their shares in respective aggregated sector.

Source: authors based on Croatian Bureau of Statistics (2010, 2011a, 2011b, 2015), Croatian Employment Service (2011), FINA (2015), Ministry of Finance (2010).

Source: Muhammad et al. (2011), Hertel et al. (2014)

Source: Muhammad et al. (2011), Croatian Employment Service (2011), Croatian Bureau of Statistics (2010, 2015), Eurostat (2018b), Brink et al. (2011), Ciaian and y Paloma (2011)

\section{Sectoral effects of nitrogen pollution reduction policy measures in Croatia}

In this section we present simulation results of selected agri-environmental policies designed to decrease agricultural nitrogen pollution in Croatia. All results are presented as a percentage changes between the initial and the post-policy equilibrium values of sectoral production, consumption, exports and imports. Policy effects are analyzed for a targeted $1 \%$ to $20 \%$ decrease of nitrogen fertilizers usage in agriculture which is approximated by the agricultural intermediate consumption of chemical industry products within the $\mathrm{BC}$ sector. In the case when a policy has no potential to decrease the use of nitrogen fertilizers in agriculture, results are presented for another potential environmental goal, i.e. agricultural land increase up to $20 \%$ which is not unrealistic target in Croatia. A measure is considered to be efficient if its implementation leads to a

Table 3 Other predetermined parameters

\begin{tabular}{lllllll}
\hline Frisch & $z^{a}$ & NOxSHARE $_{A}{ }^{b}$ & NOXFACTOR $_{A}{ }^{c}$ & $E_{N}{ }^{d}$ & $\varphi^{e}$ & $\theta^{f}$ \\
\hline-1.36 & $28 \%$ & $48 \%$ & $0.029 \mathrm{tN} / 000 \mathrm{kn}$ & $86.29 \mathrm{t}$ & $75,000 \mathrm{kn} / \mathrm{t}$ & $1.065000 \mathrm{kn} / \mathrm{ha}$
\end{tabular}

${ }^{\mathrm{a}}$ Unemployment benefits share in labor income (wage); ${ }^{\mathrm{b}}$ Share of chemical industry input in total demand of agriculture for products of the $\mathrm{BC}$ sector; ${ }^{\mathrm{C}}$ Conversion factor (gross nutrient balance divided by total demand of agriculture for products of the BC sector) in tones of nutrient per 1000 kuna of BC input; ${ }^{d}$ Nitrogen pollution (gross nutrient balance); ${ }^{e}$ Marginal social cost nitrogen pollution; ${ }^{\mathrm{f}}$ Marginal social benefits of agricultural land 
targeted nitrogen fertilizer consumption reduction (by $1 \%, 5 \%, 10 \%$ or $20 \%$ ). On the other side, a measure is considered to be effective if it reaches certain targeted level of nitrogen fertilizer consumption reduction at the lowest agricultural production and consumption losses.

\section{Sectoral effects of market-based nitrogen pollution reduction policy measures Polluter-pays principle measures}

Figures $6,7,8,9,10,11$ show simulated sectoral effects of the market-based measures which are primarily based on a polluter-pays principle. The vertical axis shows the percentage change of production, consumption, exports and imports in the post-policy equilibrium for all sectors. The bars represent the reaction of different sectors at targeted $1 \%$ to $20 \%$ decrease of nitrogen fertilizers use in agriculture. Alternative targets are marked by different colors.

Figures 6, 7, 8 show simulated sectoral effects of the polluting (agricultural) good tax, among which Figs. 7 and 8 assume neutralization of increased polluting goods tax using labor and income taxes in a way that government revenues remain unchanged after the policy implementation.

Simulation results presented in Fig. 6 show that this measure has the potential to reach targeted decrease nitrogen fertilizers use in the agricultural sector, i.e. it is efficient. However, regardless of neutralization, tax on polluting good leads to a large decrease in production, consumption and foreign trade in all sectors, especially in agriculture. Namely, at targeted $20 \%$ nitrogen fertilizers use reduction, agricultural production and consumption drop by more than $20 \%$. It should be noted that the agricultural consumption decreases more than the production since agricultural producers increase their export to foreign markets at the onset of domestic consumption decrease induced by higher taxes. Although this measure efficiently reaches nitrogen reduction target it

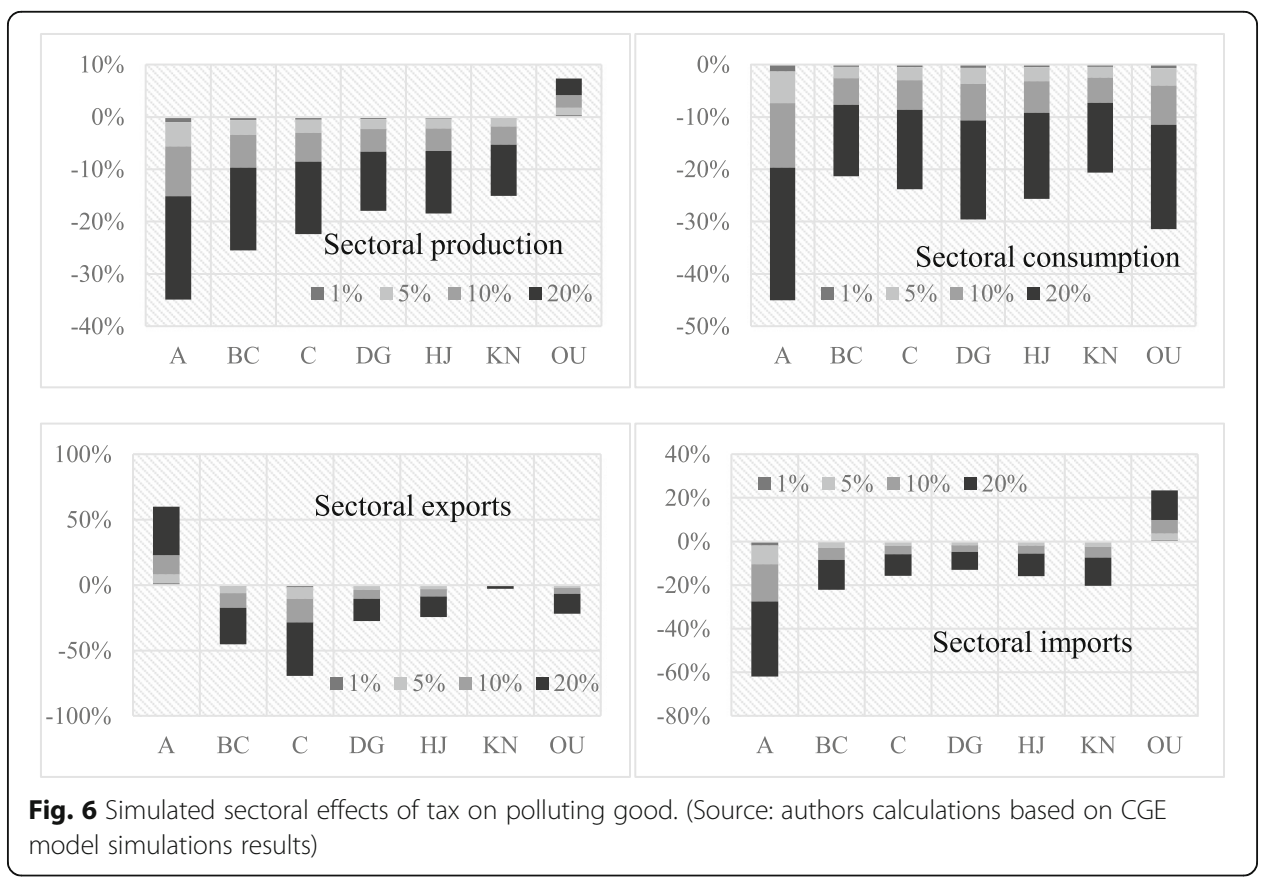




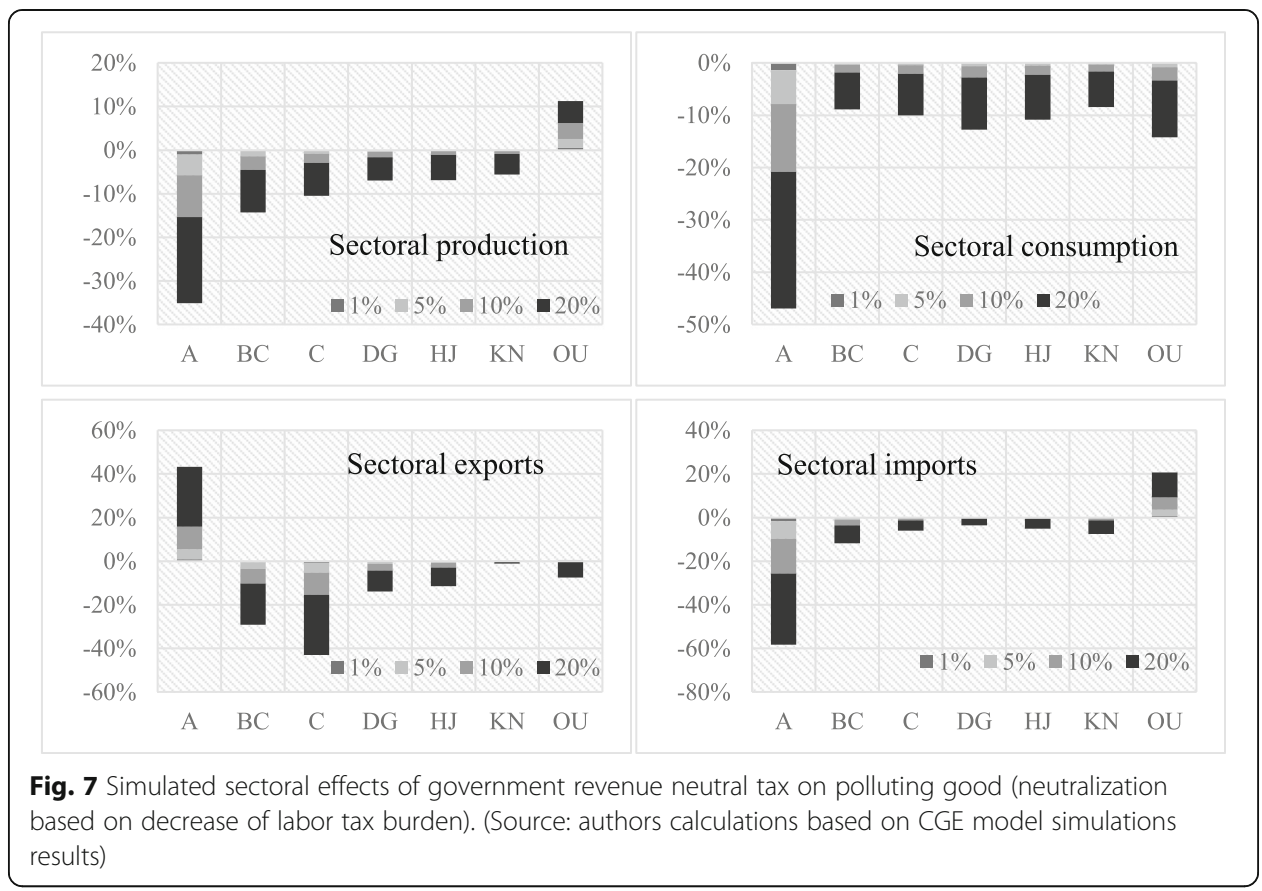

lowers the consumption more than the production where the latter is assumed to be the main source of nitrogen pollution.

Overall, increased consumption taxes seem to have relatively large adverse sectoral effects on all sectors even when government compensates them by reducing labor (Fig. 7) and income taxes.

Namely, regardless of the tax by which government tries to compensate for the higher polluting good tax, negative effects on agricultural goods consumption and production stay virtually the same. This result is not surprising since Croatia already has

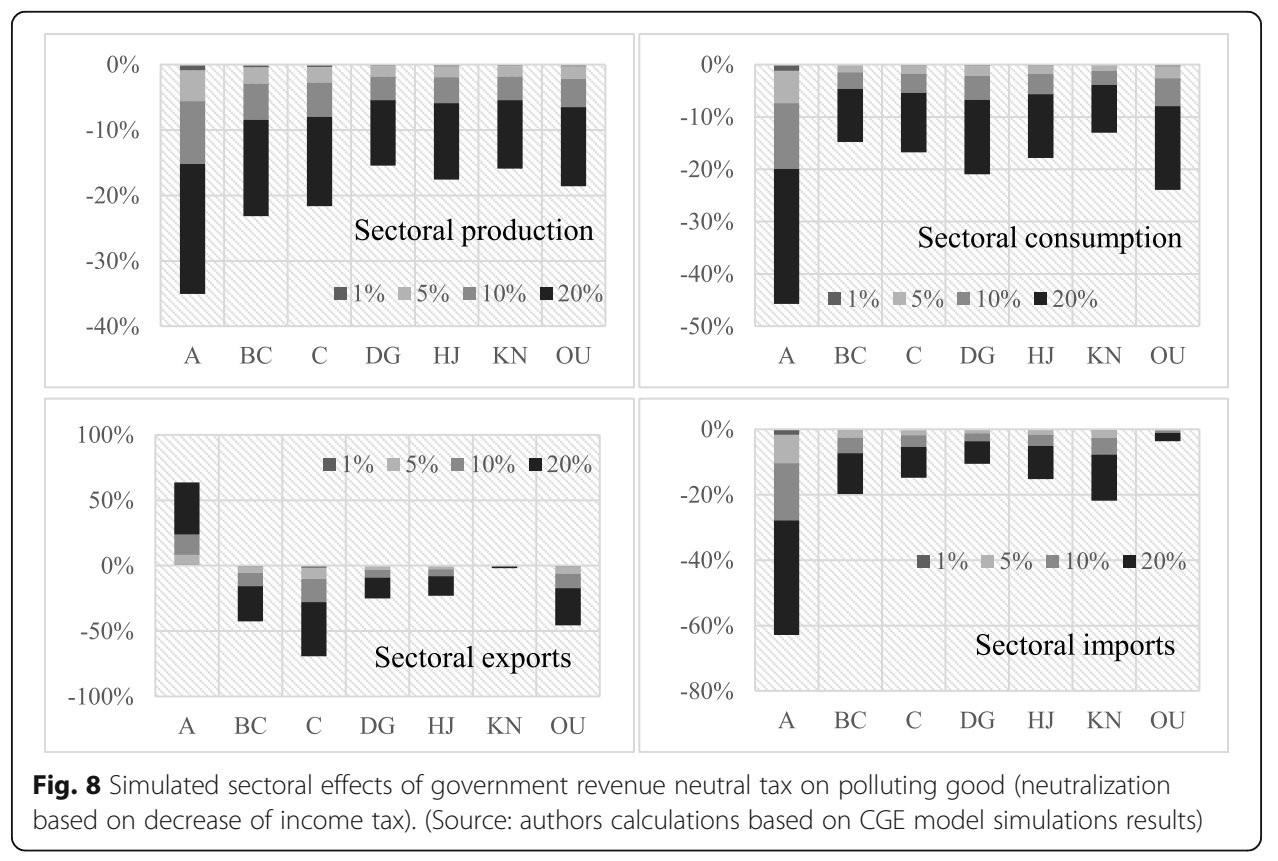




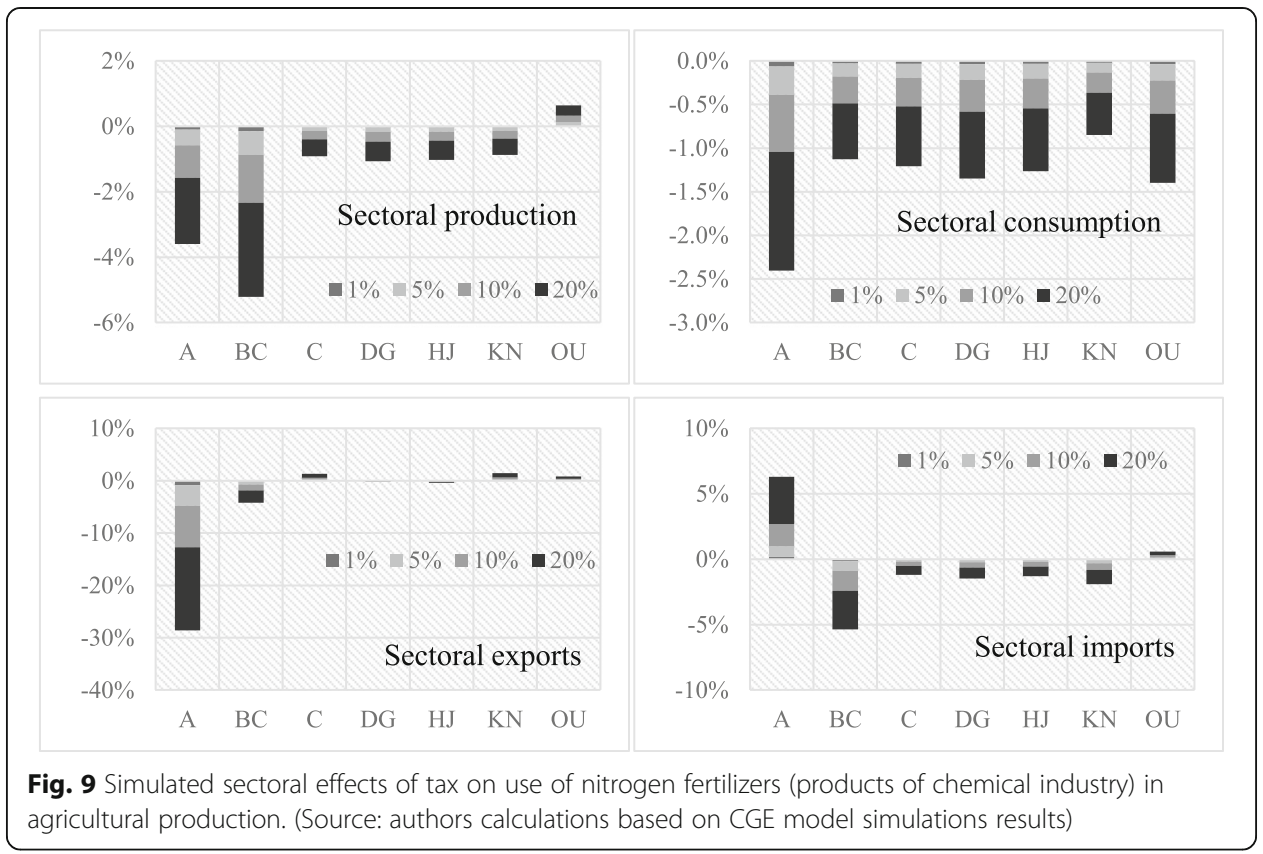

relatively high consumption taxes and the effects of tax changes on output are shown to be highly non-linear (for example, Gunter et al. (2018) estimations suggest that tax multiplier is essentially zero under relatively low/moderate initial tax rate levels and more negative as the initial tax rate and the size of the change in the tax rate increase). However, adverse effects on other sectors are at least partially hampered by tax neutralization, especially in the case of the labor tax relaxation (Fig. 7). In summary, this measure generates the highest aggregated drop in production, consumption and foreign trade even when it is followed by labor and income tax reduction.

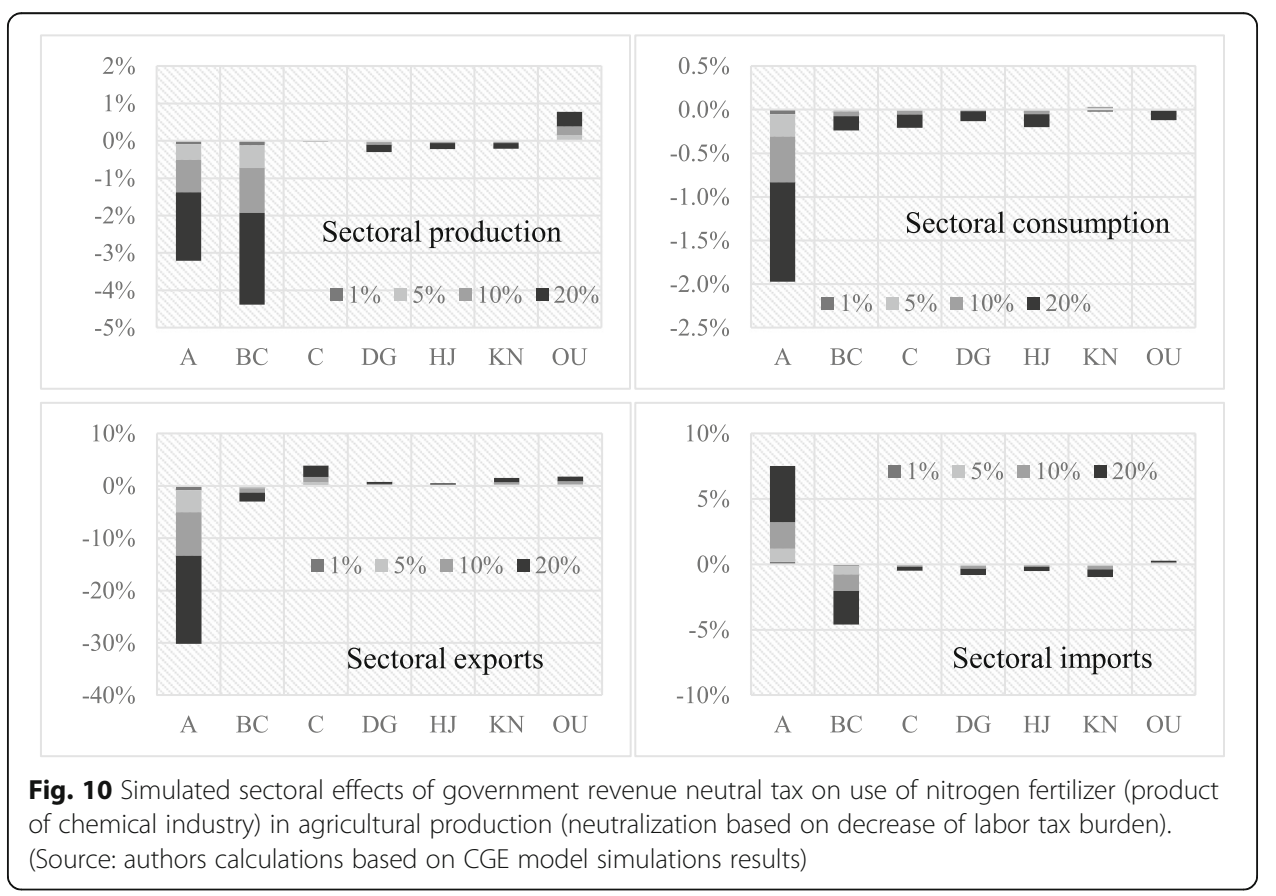




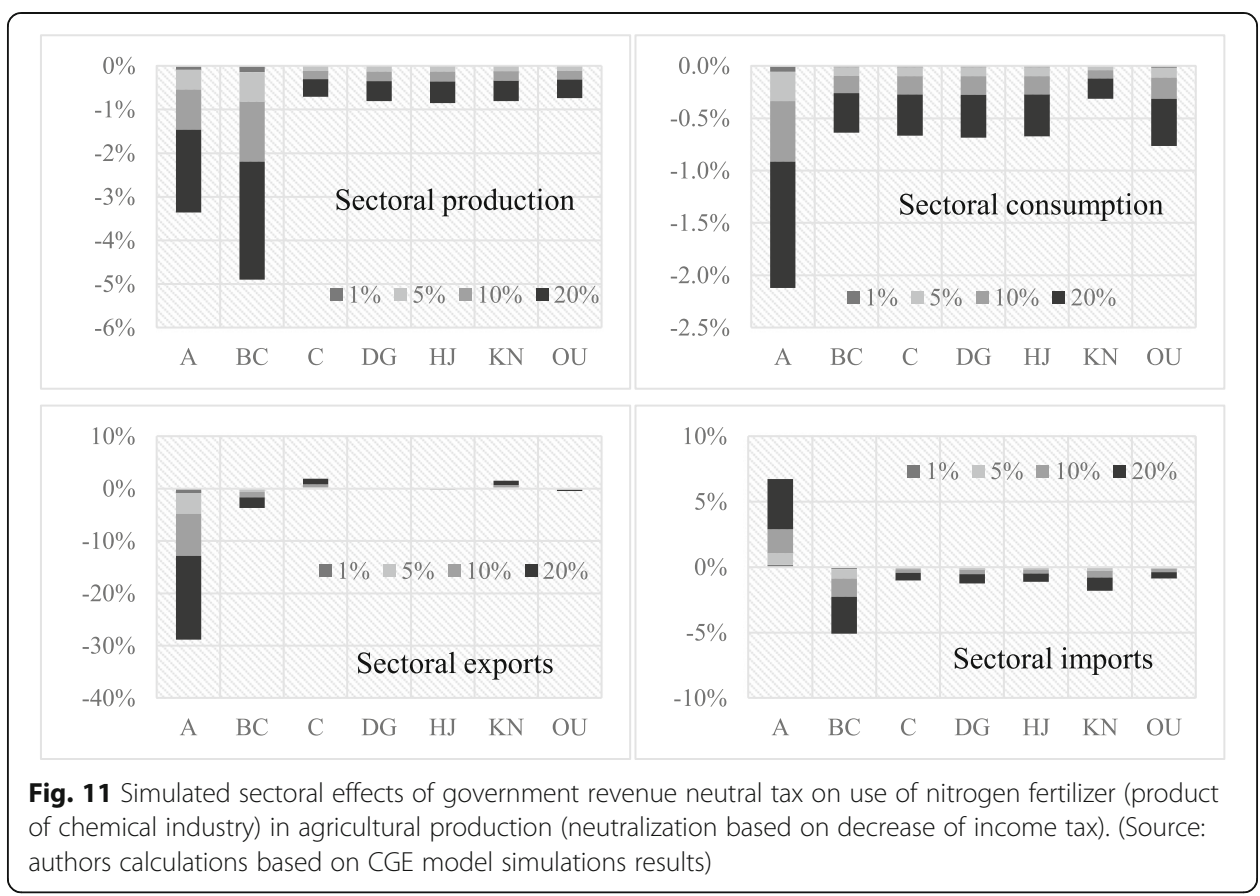

Figures 9, 10, 11 show simulated sectoral effects of a tax on nitrogen fertilizers usage (products of chemical industry) in the agricultural production, among which Figs. 10 and 11 assume government revenues neutral policy within which government changes labor and income taxes to compensate for a newly introduced nitrogen fertilizers tax.

Simulation results presented in Fig. 9 show that this measure is also efficient i.e. it has the potential to reach the targeted decrease of nitrogen fertilizers usage in agriculture. As expected, this measure has the largest negative effect on the production of the sector which is being taxed (i.e. BC). The decrease of the production and consumption of this sector is followed by a relatively large drop of the agricultural production and consumption. As this measure increases the agricultural production costs it generates competitiveness losses.

Therefore, as opposed to the previously analyzed consumption-based taxes, this measure reduces agricultural export and stimulates imports. Consequently, a tax on nitrogen fertilizers usage (products of chemical industry) in agricultural production reduces the agricultural production more than consumption. Although tax on nitrogen fertilizers usage in the agricultural sector has negative effects on production and consumption of all sectors, these adverse effects are much less pronounced than in the case of previously analyzed consumption-based taxes. However, agricultural goods export experiences relatively large decrease due to the competitiveness issues after the tax implementation. Additionally, except its adverse effects on the agricultural trade balance, the tax on use of nitrogen fertilizers in agricultural production has negligible effects on the export and import of other sectors. Moreover, when the nitrogen tax is followed by labor (Fig. 10) and income taxes (Fig. 11) reduction most of the negative effects on sectoral production, consumption and foreign trade are completely recompensated, except in the agricultural and $\mathrm{BC}$ sector. 
Aggregate decrease of consumption and production is virtually non-existent when the tax on use of nitrogen fertilizers in agricultural production is neutralized by the labor tax decrease (Fig. 10). Since negative effects on consumption mostly arise from the reaction of labor market after the imposition of polluter-pays agri-environmental measures (i.e. increased unemployment), the labor tax reduction proves to be the most appropriate tool for mitigating negative (side)effects of taxes-based nitrogen reduction policy measures than the income tax reduction.

\section{Provider-gets principle measure}

Figure 12 depicts simulated sectoral effects of government revenue neutral subsidy for benefits provided by agriculture (neutralization based on consumption tax change). This is the only measure which is not efficient in nitrogen fertilizer reduction. Although land and nitrogen fertilizers are assumed to be substitutable in the agricultural production this measure increases agricultural production and exports enough to fail to reduce the nitrogen fertilizers consumption in agriculture. Therefore, the results presented in Fig. 12 are analyzed for a targeted 1\%,5\%,10\% and 20\% increase of the agricultural land.

According to the results presented in Fig. 12 this measure increases production of almost all sectors. As this measure implies lower consumption taxes and introduction of land subsidies it generates positive employment, aggregate consumption and foreign trade changes which are most pronounced in the agricultural sector. However, as government revenues neutral subsidy on agricultural land expansion implies reduction of consumption taxes (due to the subsidies induced employment and production growth) it increases the use of nitrogen fertilizers in agriculture. Therefore, this measure is inefficient in agricultural nitrogen pollution reduction.

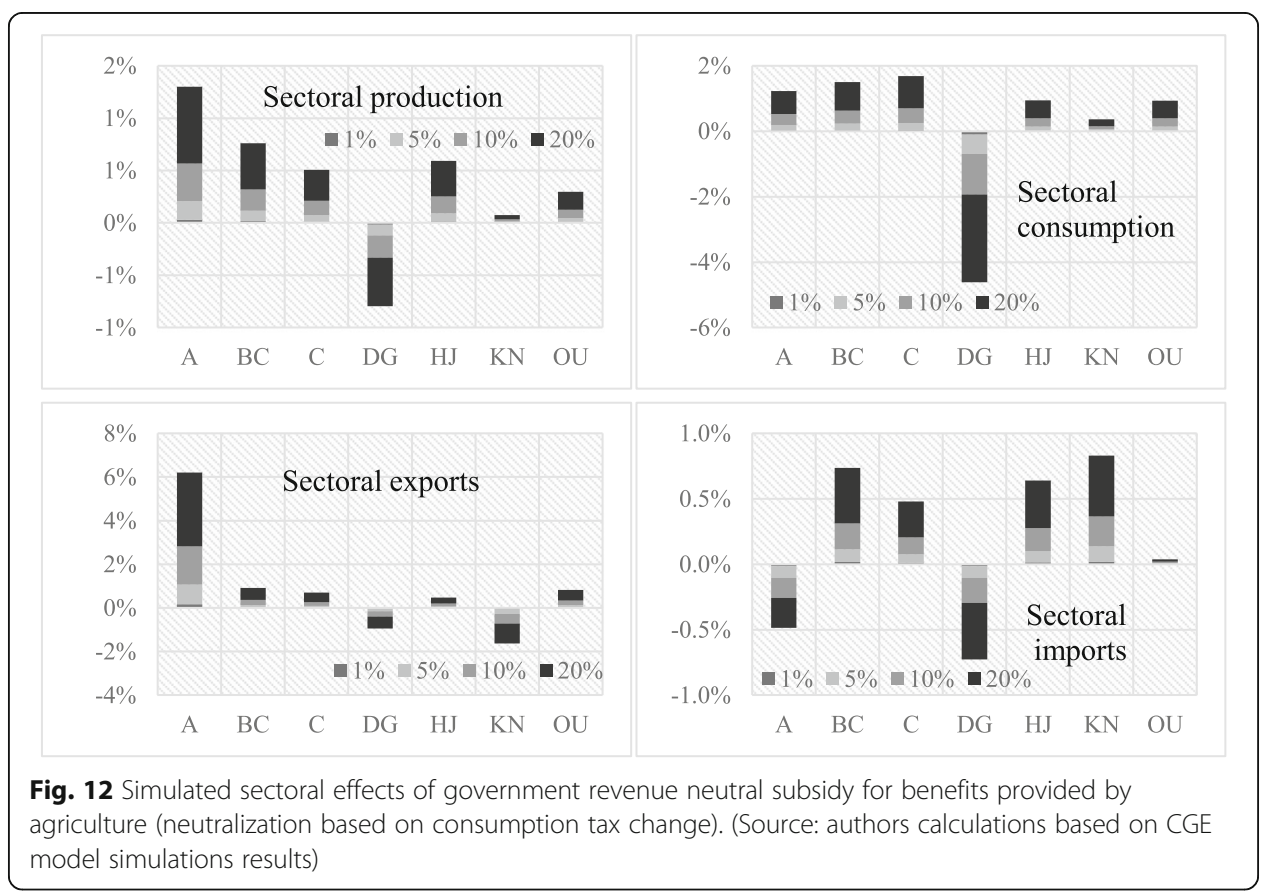




\section{Combined (polluter-pays and provider-gets principle) measure}

Figure 13 depicts simulated sectoral effects of the combination of a subsidy for benefits provided by agriculture and a tax on use of nitrogen fertilizers (product of chemical industry) in agriculture.

Simulation results presented in Fig. 13 show that this measure is efficient in reaching the maximum reduction of the nitrogen fertilizers usage in agriculture by $17 \%$. However, this is the only measure which decreases agricultural nitrogen pollution without adverse effects on aggregate consumption and agricultural production/consumption. Although this measure results with a slightly higher aggregate production drop than tax on use of nitrogen fertilizers in agricultural production (-3\% vs $-1 \%)$ we regard it as being the most effective due to its positive effects on agricultural production, mild aggregate consumption growth (1\%) and its positive effects on agricultural amenities due to the land subsidies. As it is evident from Fig. 13 the implementation of a subsidy for benefits provided by agriculture and a tax on use of nitrogen fertilizers leads to an increase of the agricultural export and a decrease of the agricultural import due to the competitiveness gains resulting from land subsidies. However, most of the economic sectors experience mild production and foreign trade decrease after the implementation of this measure.

\section{Sectoral effects of regulatory nitrogen pollution reduction policy measures}

Figures 14 and 15 depict simulated sectoral effects of two regulatory measures, i.e. quantitative requests to decrease the use of mineral fertilizers in agriculture and quantitative requests to increase the land use in agricultural production.

The results presented in Fig. 14 reveal that quantitative requests to decrease the chemical industry products usage in agriculture have relatively large negative effects on production, consumption and trade in all analyzed sectors. Agricultural sector records

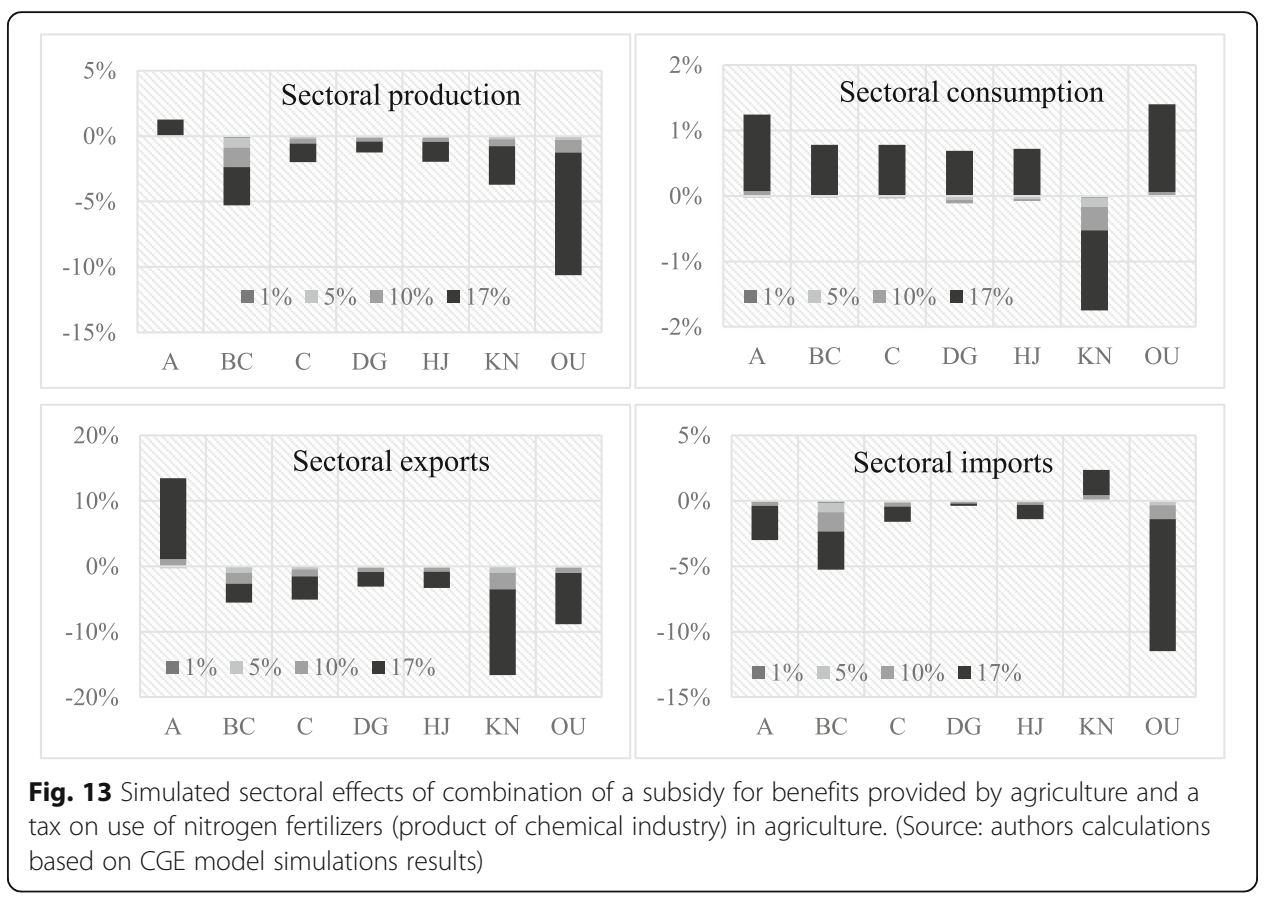




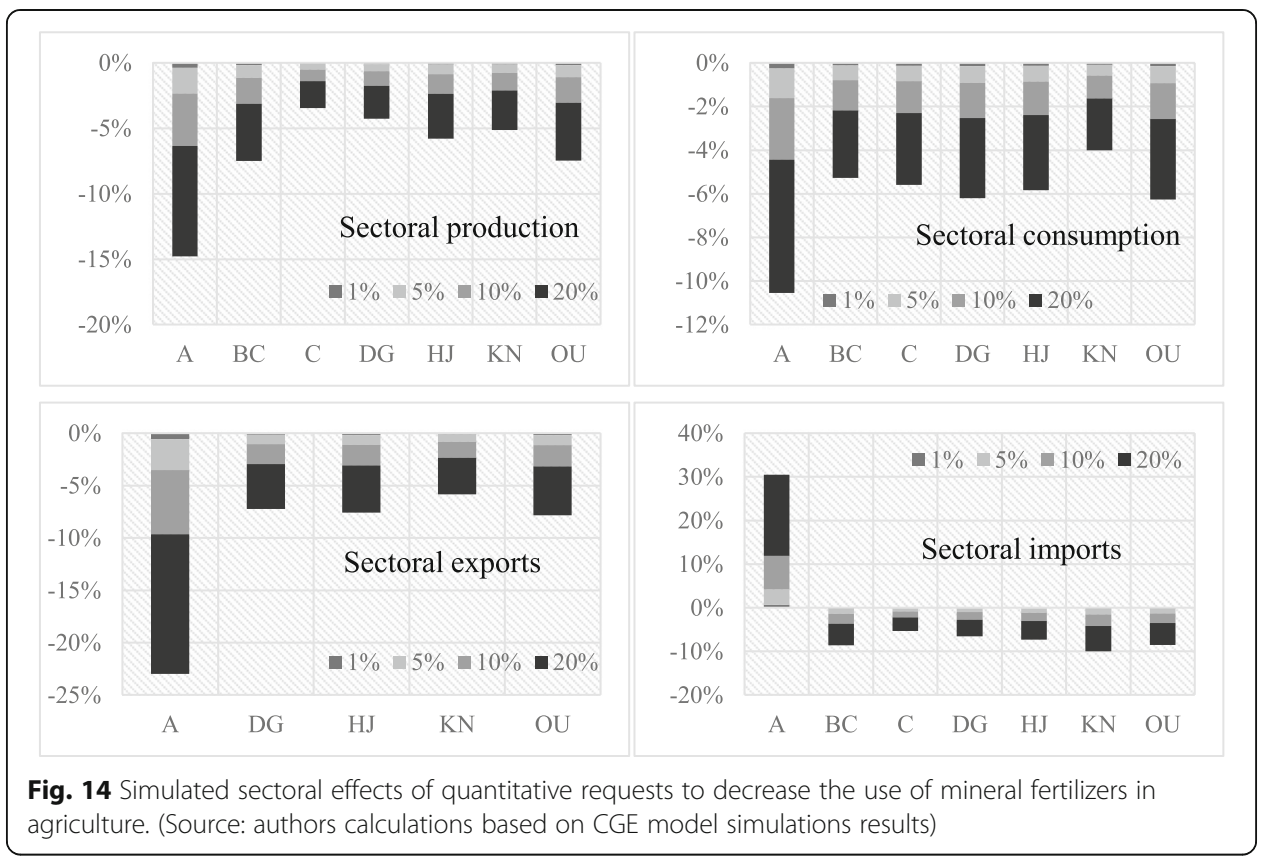

the largest decrease of production, consumption and exports and is the only sector in which import grows after the policy implementation.

Simulation results presented in Fig. 15 show that the introduction of quantitative requests to increase agricultural land has the strongest negative impact on the $\mathrm{BC}$ sector.

Therefore, unlike the quantitative requests to decrease the usage of chemical industry products in agriculture, which affect the agricultural sector the most, quantitative requests to increase agricultural land impact $\mathrm{BC}$ sector the most. This result is consistent with the assumption that land and $\mathrm{BC}$ sector's products are substitutable in agricultural

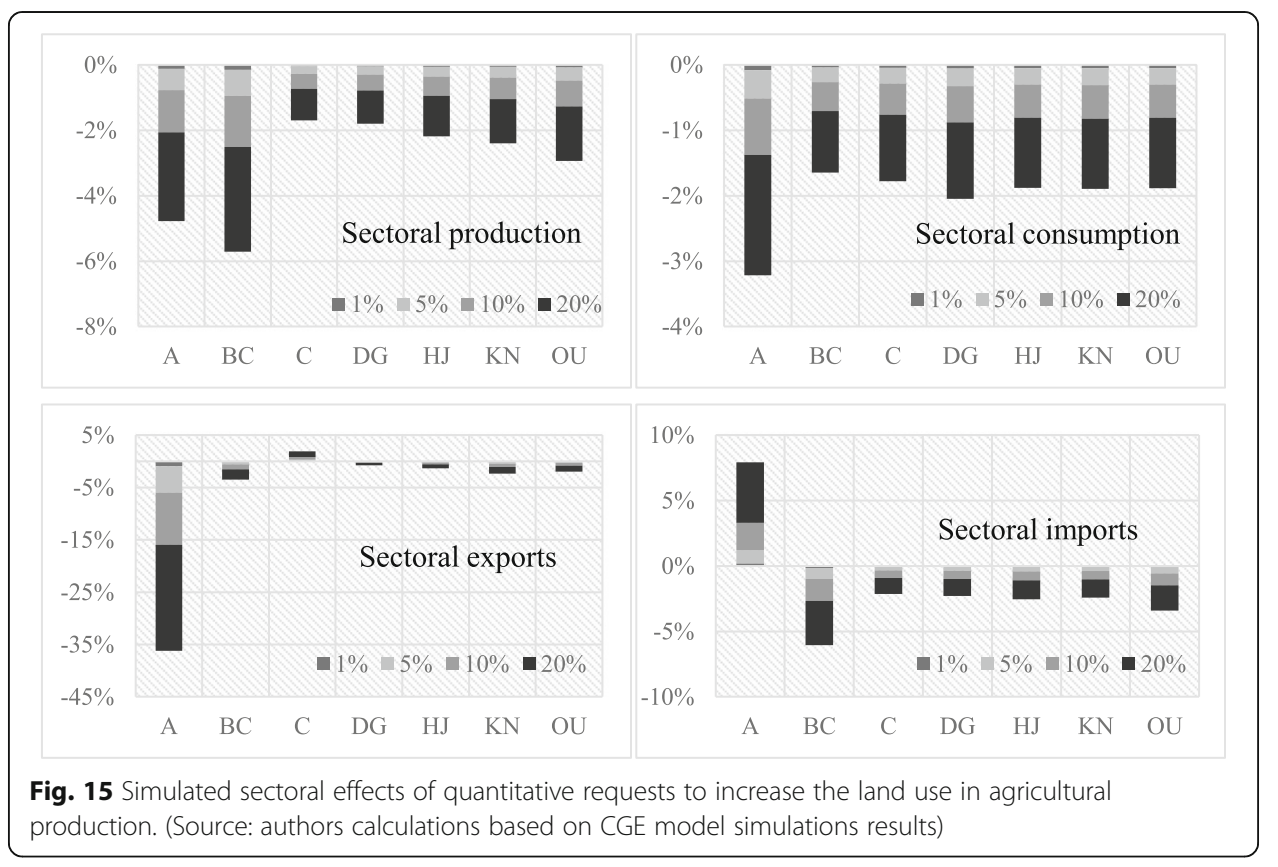


production process, whereas increased use of land in agriculture lowers the demand of the agricultural sector for this (BC sector) intermediate products.

Generally, both regulatory measures decrease exports of most sectors due to their negative effects on the production of all sectors. However, there are some differences between the two regulatory measures. Namely, quantitative requests to decrease the use of mineral fertilizers in agriculture decrease agricultural export less than quantitative requests for increasing agricultural land usage, while the opposite is true for all other sectors.

Although Figs. 14 and 15 suggest that analyzed regulatory measures share many similarities (regarding the direction of the sectoral effects), adverse sectoral effects of the quantitative requests to increase agricultural land seem to be less pronounced. Therefore, since both measures seem to be efficient in agricultural nitrogen pollution reduction, quantitative requests to increase the agricultural land should be preferred to the quantitative requests to decrease the mineral fertilizers usage in agriculture due to weaker adverse agricultural and aggregate effects $(-2 \%$ vs $-4 \%$ for aggregate production and $-1 \%$ vs $-4 \%$ in the case of aggregate consumption).

It is interesting to note that negative sectoral and aggregate effects of both regulatory policies are significantly lower compared to the negative effects induced by the agricultural goods tax, especially when compared to quantitative requests to increase the agricultural land. This conclusion contradicts standard theoretical conclusions which usually regard market-based-measures as being less distortive than regulatory measures.

\section{Concluding remarks and policy recommendations}

To tackle nitrogen pollution related problems, the EU recognized emissions resulting from agricultural activities as one of the four major areas of action regarding environmental problems. As an EU member state, Croatia has the obligation to implement supranational agri-environmental policies which will become an even more important part of the CAP framework. Due to its potential economy-wide (side)effects it is important to anticipate potential sectoral effects of nitrogen pollution reduction policies. In this paper we employed standard CGE modeling technique to evaluate the economy-wide sectoral effects of several agricultural nitrogen pollution reduction measures in the presence of pollution disutility, agricultural amenities and labor market imperfections. The paper analyzed sectoral effects of two sets of potential policies, i.e. market-based and regulatory policy measures. CGE based sectoral effects analysis showed that all agri-environmental measures can have relatively large effects on all sectors in Croatia. Few generalized conclusions and policy recommendations emerged.

First, government revenue neutral tax on nitrogen fertilizer usage in the agricultural production (neutralization based on decrease of labor tax burden) is proven to have the least negative impacts on sectoral production, consumption and exports. However, from the social welfare point of view, a combination of a subsidy for benefits provided by agriculture and a tax on use of nitrogen fertilizers is the only policy mix that manages to achieve nitrogen reduction and increase social welfare simultaneously. Additionally, this measure (together with regulatory measures) has the highest negative impact on exports of agricultural goods. This is the result of competitiveness losses in 
agricultural sector due to increased production costs where Croatia, as a small open economy, is faced with given world export prices.

Second, government revenue neutral subsidy for benefits provided by agriculture (neutralization based on consumption tax change) has positive sectoral and economywide effects but it cannot be used to decrease agricultural nitrogen pollution since it increases it.

Thirdly, in an already highly taxed economy introduction of tax on polluting good and government revenue neutral tax on polluting good implies quite significant production and consumption losses. However, even if this measure efficiently reduces agricultural nitrogen pollution, we can observe disproportionate effect on the consumption and production. Namely, a drop in the consumption of agricultural goods in the domestic economy after introduction of the tax will not proportionally lower the production since producers can export their unsold products. In line with the later, effectiveness of such policy is lower than of the policy directed to the pollution source which comes from the producer. Given the fact that pollution is created on the production side, it should also be taxed there.

Finally, among efficient nitrogen reduction measures, regulatory measures are inferior to nitrogen taxes-based (market) measures The same does not hold for the polluting (agricultural) goods taxes-based (market) measure. Namely, aggregate production and consumption losses are larger in the case of the tax on a polluting (agricultural) goods then in the case of analyzed regulatory measures. Still, although regulatory policy measures prove to be efficient in agricultural nitrogen pollution reduction, both analyzed measures have significant negative effects on all sectors.

It can be concluded that the implementation of any agri-environmental policy measure should be accompanied by a detailed sectoral analysis to assess and prevent possible negative side-effects. Also, it should be noted that in Croatia the "pure" polluter-pays principle-based measures could have relatively large adverse economy-wide effects mostly due to negative labor market effects. Thus, to mitigate potential negative sideeffects of nitrogen reduction policies, it is necessary to complement these policies with compensating measures that have the potential to (if not to prevent then) at least mitigate foreseeable adverse general equilibrium effects.

\section{Appendix}

Model is partially based on EcoMod (2015) and we follow standard EcoMod's notation.

\section{Consumers}

Consumers choose a combination of seven goods which maximize their utility. Consumer utility does not depend on the consumption of market goods only, but also on the level of pollution by nitrogen fertilizers and benefits accrued by the multifunctional agriculture. It is assumed these externalities are not internalized in the initial equilibrium so consumers cannot influence the level of pollution by nitrogen fertilizers. Also, they cannot influence the provided level of benefits given by agricultural landscape. Their utility function is presumably separated and linear in environmental goods. Utility function of a representative household is given by Stone-Geary linear system of expenditures. This functional form is selected due to its flexibility relative to other 
functional forms (Burfisher 2011). A representative household maximizes its utility function:

$$
U=\beta_{H} \prod_{i=1}^{7}\left(C_{i}-\ddot{\mathrm{E}}_{i}\right)^{a_{i}}-\phi E_{N}+\theta E_{B}
$$

where $i$ is a set of goods/sectors consisting of seven goods. $C_{i}$ represents consumption of a good $i$ by the household. $\mu_{i}$ is the subsistence level of consumption of $i$-th good. Also, $C_{i}>\mu_{i} \geq 0 \quad \forall i, \alpha_{i}>0$ and $\sum_{i=1}^{7} \alpha_{i}=1 . \alpha_{i}$ resembles the Cobb-Douglas share parameters but only after consumption reaches subsistence level.

$\phi$ represents marginal social cost of nitrogen pollution $\left(E_{N}\right)$, and $\theta$ stands for marginal social benefits $\left(E_{B}\right) . E_{N}$ and $E_{B}$ are exogenously given to consumer and are greater than 0 . Nitrogen pollution is a linear function of nitrogen fertilizers used in agricultural production (labeled as $\left.B_{A}\right)$ corrected for the conversion factor $\left(N O x F A C T O R_{A}\right)$ and share of chemical industry goods used in agricultural production within total demand of agriculture for goods produced by $\mathrm{BC}$ sector $\left(N O x S H A R E_{A}\right)$. On the other hand, environmental benefits are a linear function of used agricultural land labeled as $Z_{A}$.

$$
\begin{aligned}
& E_{N}=N O x F A C T O R_{A} N O x S H A R E_{A} B_{A}=N O x G N B_{A} \\
& E_{B}=Z_{A}
\end{aligned}
$$

A consumer's budget $(C B U D)$ is given by:

$$
C B U D=\left(1-t_{Y}\right) Y-S_{H}
$$

where $Y$ stands for income, $t_{Y}$ is income tax, and $S_{H}$ are savings. Income is equal to:

$$
Y=P_{L}\left(L_{s}-U_{N}\right)+P_{K}\left(K_{s}\right)+P_{Z}\left(Z_{s}\right)+T R F
$$

In (11) $P_{L}$ represents wage, $L_{S}$ is labor supply, $P_{Z}$ is land rent, $Z_{S}$ is land supply, $P_{K}$ is the capital price, and $K_{s}$ is capital supply. TRF represents total government transfers to consumers. Consumer savings are determined by the exogenously given marginal savings rate $\left(m p s_{H}\right)$ and after-tax income:

$$
S_{H}=m p s_{H}\left(Y-t_{Y} Y\right)
$$

Consumer choice is subject to a budget constraint given by:

$$
Y \geq S_{H}+t_{Y} Y+\sum_{i=1}^{7}\left(1+t c_{i}\right) P_{i} C_{i}
$$

where $P_{i}$ are prices of final goods, and $t c_{i}$ are consumption taxes. Solution of problem (7), subject to (13), yields consumer demand function $\left(C_{i}\right)$ : 


$$
C_{i}=\left[\left(1+t c_{i}\right) P_{i} \mu_{i}+a_{i} P_{i}\left(\left(1-t_{Y}\right) Y-S_{H^{-}} \sum_{i=1}^{7}\left(1+t c_{i}\right) P_{i} \mu_{i}\right)\right] /\left[\left(1+? t c ?_{i}\right) P_{i}\right]
$$

\section{Producers}

We assume substitutability of primary factors of production and products of chemical industry in agricultural production process. Substitutability assumption is based on the premise that it is possible, at least to some extent, to substitute chemical industry products (proxy for nitrogen fertilizers) with other factors of production such as land. Given the natural characteristics of Croatia this assumption seemed reasonable.

In a production process profit maximizing firms are limited by multilevel production function. At the first level factors of production are combined (labor, capital, land and BC sector goods bundle - $\left.K L Z B_{i}\right)$ with intermediate inputs $\left(I O_{n i, j}\right)$ in fixed proportions to produce domestic goods $\left(X D_{i}\right)$. Therefore, production of domestic goods $\left(X D_{i}\right)$ is given by:

$$
X D_{i}=f\left(K L Z B_{i}, I O_{n i, i}\right)
$$

where

$$
K L Z B_{i}=b_{i} X D_{i}
$$

$$
I O_{i}=\left(1-b_{i}\right) X D_{i}
$$

whereas $n i$ is a set of goods/sectors consisting of 6 intermediate goods, $b_{i}$ is a share of the capital, labor, land and $\mathrm{BC}$ sector goods bundle in a domestic good, and $\left(1-b_{i}\right)$ is a share of intermediates (without the $\mathrm{BC}$ sector). Capital, labor, land and $\mathrm{BC}$ sector goods bundle is the function of capital and labor bundle and land and $\mathrm{BC}$ sector goods bundle:

$$
K L Z B_{i}=f\left(K L_{i}, Z B_{i}\right)
$$

Also, from (16) it is clear that

$$
X D_{i}=\left(1 / b_{i}\right) K L Z B_{i}
$$

where

$$
\frac{1}{b_{i}}=a F 1_{i}
$$

At the second level firms choose combination of the capital and labor bundle $\left(K L_{i}\right)$ and a land and $\mathrm{BC}$ sector good bundle $\left(Z B_{i}\right)$ by minimizing the production costs given by:

$$
\min K L_{i} P K L_{i}+Z B_{i} P Z B_{i}
$$




$$
K L Z B_{i}=a F 2_{i} K L_{i}^{\alpha 2_{i}} Z B_{i}^{\left(1-\alpha 2_{i}\right)}
$$

Solution of this problem leads to demand functions for capital and labor $\left(K L_{i}\right)$ and land and $\mathrm{BC}$ sector goods $\left(Z B_{i}\right)$ bundles:

$$
\begin{aligned}
& K L_{i}=\frac{K L Z B_{i}}{a F 2_{i}}\left[\frac{\alpha 2_{i}}{\left(1-\alpha 2_{i}\right)} \frac{P Z B_{i}}{P K L_{i}}\right]^{\left(1-\alpha 2_{i}\right)} \\
& Z B_{i}=\frac{K L Z B_{i}}{a F 2_{i}}\left[\frac{\left(1-\alpha 2_{i}\right)}{\alpha 2_{i}} \frac{P K L_{i}}{P Z B_{i}}\right]^{\alpha 2_{i}}
\end{aligned}
$$

Where $P K L_{i}$ and $P Z B_{i}$ stand for capital-labor and land-BC sector goods bundles prices, parameter $\alpha 2_{i}$ is less than 1 and defines capital and labor $\left(K L_{i}\right)$ bundle share in the $K L Z B_{i} \cdot a F 2_{i}$ is a shift parameter of the production function, i.e. technology parameter. Zero profits condition is given by:

$$
K L Z B_{i} P K L Z B_{i}=K L_{i} P K L_{i}+Z B_{i} P Z B_{i}
$$

Condition (25) determines capital, labor, land and BC sector goods bundle prices $\left(P K L Z B_{i}\right)$, and (23) and (24) determine firms demand for capital and labor bundle and land and $\mathrm{BC}$ sector goods bundle. From (17) it is clear that $X D_{i}=\frac{I O_{i}}{1-b_{i}}$. Therefore, demand for intermediates is given by:

$$
X D_{n i, i}=d_{n i, i} I O_{i}
$$

where $d_{n i, i}$ represents the share of $\mathrm{n} i$-ths sector good in $i$-th sector intermediate goods demand. Here, $\sum_{n i, i=1}^{6} d_{n i, i}=1$. By defining the matrix of technical coefficients $\left(i o_{n i, i}\right)$ :

$$
i o_{n i, i}=\left(1-b_{i}\right) d_{n i, i}
$$

Intermediate demand of the $i$-th sector for $n i$-th sector goods is given by:

$$
X D_{n i, i}=i o_{n i, i} X D_{i}
$$

At the third level firms choose a combination of capital and labor $\left(K L_{i}\right)$ which minimizes their cost given the CES production function:

$$
\min K_{i}\left(1+t k_{i}\right) P_{K}+L_{i}\left(1+t l_{i}\right) P_{L}
$$

Subject to

$$
K L_{i}=a F 3 a_{i}\left(\gamma 3^{V A_{i}} K_{i}^{-\rho 3_{V A_{i}}}+\left(1-\gamma 3^{V A_{i}}\right) L_{i}^{-\rho 3_{V A_{i}}}\right)^{-1 / \rho 3_{V A_{i}}}
$$

Solution gives capital $\left(K_{i}\right)$ and labor $\left(L_{i}\right)$ demand: 


$$
\begin{aligned}
& K_{i}=\left(\frac{K L_{i}}{a F 3 a_{i}}\right) \\
& \left\{\left(\gamma 3^{V A_{i}}\right)^{\sigma 3_{V A_{i}}}\left(1+t k_{i}\right) P_{K}^{-\sigma 3_{V A_{i}}}\left[\left(\gamma 3^{V A_{i}}\right)^{\sigma 3_{V A_{i}}}\left(1+t k_{i}\right) P_{K}{ }^{1-\sigma 3_{V A_{i}}}+\left(1-\gamma 3^{V A_{i}}\right)^{\sigma 3_{V A_{i}}}\left(1+t l_{i}\right) P_{L}{ }^{1-\sigma 3_{V A_{i}}}\right]^{\left.\frac{{ }^{\sigma 3} V A_{i}}{\left(1-\sigma 3_{V A}\right.}\right)}\right\} \\
& L_{i}=\left(\frac{K L_{i}}{a F 3 a_{i}}\right)
\end{aligned}
$$

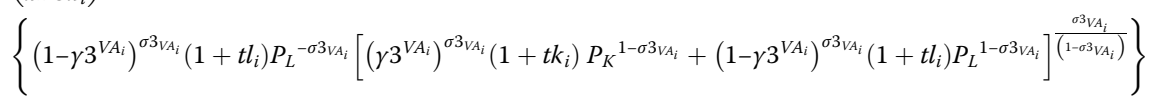

Where $P_{L}$ and $P_{K}$ represent labor and capital prices, parameter $a F 3 a_{i}$ is a shift parameter. $\sigma 3_{V A_{i}}=1 /\left(1+\rho 3_{V A_{i}}\right)$ represents elasticity of substitution, while $t l_{i}$ and $t k_{i}$ represent labor and capital taxes respectively. Zero profit condition is given by:

$$
K L_{i} P K L_{i}=K_{i}\left(1+t k_{i}\right) P_{K}+L_{i}\left(1+t l_{i}\right) P_{L}
$$

Equation (33) determines capital and labor bundles prices $\left(P K L_{i}\right)$.

Firms also choose land and BC sector goods combination which minimizes costs given the Cobb-Douglas production function:

$$
\min Z_{i} P_{Z}+B_{i} P_{i=B C}
$$

Subject to

$$
Z B_{i}=a F 3 b_{i} Z_{i}^{\alpha 3_{i}} B_{i}^{\left(1-\alpha 3_{i}\right)}
$$

Solution leads to land $\left(Z_{i}\right)$ and $\mathrm{BC}$ sector good $\left(B_{i}\right)$ demand functions:

$$
\begin{aligned}
& Z_{i}=\frac{Z B_{i}}{a F 3 b_{i}}\left[\frac{\alpha 3_{i}}{\left(1-\alpha 3_{i}\right)} \frac{P_{i=B C}}{P_{Z}}\right]^{\left(1-\alpha 3_{i}\right)} \\
& B_{i}=\frac{Z B_{i}}{a F 3 b_{i}}\left[\frac{\left(1-\alpha 3_{i}\right)}{\alpha 3_{i}} \frac{P_{Z}}{P_{i=B C}}\right]^{\alpha 3_{i}}
\end{aligned}
$$

Where $P_{Z}$ and $P_{i=B C}$ represent land and $\mathrm{BC}$ sector goods prices. Parameter $a F 3 b_{i}$ is a shift parameter, and parameter $\alpha 3_{i}<1$ defines a share of land in the land and $\mathrm{BC}$ sector goods bundle $\left(Z B_{i}\right)$. Zero profits condition is given by:

$$
Z B_{i} P Z B_{i}=Z_{i} P_{Z}+B_{i} P_{i=B C}
$$

Equation (32) determines land and $\mathrm{BC}$ sector goods bundle prices $\left(P Z B_{i}\right)$.

Domestic goods $\left(X D_{i}\right)$ supply is given by: 


$$
X D_{i}=\left[P K L Z B_{i} K L Z B_{i}+\sum_{n i=1}^{6} i o_{n i, i} X D_{i} P_{n i}\left(1+t i m_{i}\right)\right] / P D_{i}
$$

Equation (39) determines domestic goods prices labeled as $P D_{i}$ in. Intermediate inputs taxes are represented by $\operatorname{tim}_{i}$.

\section{Government}

It is assumed that government allocates its revenues according to the solution of the constrained utility maximization problem given by:

$$
\max U_{G}=\prod_{i=1}^{7}\left(C G_{i}\right)^{\alpha}{ }^{{ } G_{i}}
$$

where $C G_{i} \geq 0 \forall i$, and represents government consumption of goods of a sector $i .{ }^{\alpha} C G_{i}$ $\geq 0$ and $\sum_{i=1}^{7}{ }^{\alpha} C G_{i}=1$. Budget constraint is given by:

$$
T R \geq \sum_{i-1}^{7}\left(P_{i} C G_{i}\right)+T R F+S_{G} C P I
$$

where $T R$ represents government revenues, $S_{G}$ represents government savings which takes on negative values in the case of budget deficit, CPI represents consumer price index and is equal to Laspeyer price index given by:

$$
C P I^{1}=\frac{\sum_{i=1}^{7}\left(1+t c_{i}^{1}\right) P D_{i}{ }^{1} C_{i}^{0}}{\sum_{i=1}^{7}\left(1+t c_{i}{ }^{0}\right) P D_{i}{ }^{0} C_{i}{ }^{0}}
$$

where power of 1 represents the level of a variable after the introduction of agrienvironmental policy, and power of 0 represents the level of individual variable in an initial equilibrium. TRF represents government expenditures for unemployment and other transfers to households which are equal to:

$$
T R F=z P_{L} U+T R O(C P I)
$$

where $z$ represents a share of unemployment benefits in a market set price of labor (wage), and TRO represents other government transfers. The total government revenues are given by:

$$
T R=t_{Y} Y+\sum_{i=1}^{7}\left(t c_{i} P_{i} C_{i}\right)+t k_{i} K_{i} P_{K}+t l_{i} L_{i} P_{L}+\sum_{i=1}^{7} \sum_{i=1}^{7} i o_{j, i} X D_{i} P_{j} t i m_{i}
$$

Solution of the problem (40) conditional upon (41) determines the optimal level of government consumption $\left(C G_{i}\right)$ and is given by:

$$
C G_{i}=\left[{ }^{\alpha} C G_{i}\left(T R-T R F-S_{G} C P I\right)\right] / P_{i}
$$

\section{Investors}

It is assumed that an investment bank/agent allocates investments $\left(I D_{i}\right)$ in a similar way. The investment bank/agent is limited with a total savings in an economy $(S)$ given by: 


$$
S=S_{H}+S_{G} C P I+S_{F} E R
$$

where $S_{F}$ is foreign savings. It is assumed that the investment bank maximizes:

$$
\max U_{I}=\prod_{i=1}^{7}\left(I D_{i}\right)^{\alpha_{I_{i}}}
$$

In (41) $I D_{i} \geq 0 \forall i$, and it represents investments in a sector $i . \alpha_{I_{i}} \geq 0$ and $\sum_{i=1}^{7} \alpha_{I_{i}}=1$. Under the condition that total investment cannot exceed total savings:

$$
S \geq \sum_{i=1}^{7}\left(I D_{i} P_{i}\right)
$$

Thus, the investments are given by:

$$
I D_{i}=\left[\propto_{I_{i}}(S)\right] / P_{i}
$$

\section{Rest of the World}

It is assumed that Croatia is a small open economy without ability to influence world import $\left(P M_{i}^{w}\right)$ or export prices $\left(P E_{i}^{w}\right)$. It is also assumed that imported $\left(M_{i}\right)$ and domestic goods $\left(X D_{i}\right)$, and exported $\left(E_{i}\right)$ and domestic goods are imperfect substitutes. Assumption of imperfect substitutability between imported and domestic goods is called Armington assumption and implies that most goods are simultaneously imported and exported (Hosoe et al. 2015). Producers choose between selling domestic goods $\left(X D_{i}\right)$ in domestic market $\left(X D D_{i}\right)$ with price $P D D_{i}$, or in international market with world export price $P E_{i}^{w}$ denominated in domestic currency. The world import and export prices are equal to the product of exogenously given world price and nominal exchange rate $(E R)$ :

$$
\begin{aligned}
P M_{i} & =E R * P M_{i}^{w} \\
P E_{i} & =E R * P E_{i}^{w}
\end{aligned}
$$

To choose an optimal combination of supply in domestic and foreign market, producers maximize profits conditional subject to constant elasticity of transformation function $(C E T)$ :

$$
\begin{aligned}
& \max P D_{i} X D_{i}=P E_{i} E_{i}+P D D_{i} X D D_{i} \\
& X D_{i}=a T_{i}\left(\gamma_{T_{i}} E_{i}^{-\rho_{T_{i}}}+\left(1-\gamma_{T_{i}}\right) X D D_{i}^{-\rho_{T_{i}}}\right)^{-1 / \rho_{T_{i}}}
\end{aligned}
$$

where $\sigma_{T_{i}}=1 /\left(1+\rho_{T_{i}}\right)$ is export transformation elasticity. Solution of (45) conditional upon (46) leads to supply of domestic good in the domestic market and supply of domestic goods in internarial market. $a T_{i}$ is a shift parameter of the CET function. 


$$
\begin{aligned}
& X D D_{i}=\left(\frac{X D_{\mathrm{i}}}{a T_{i}}\right)\left\{\left(1-\gamma^{T_{i}}\right)^{\sigma_{T_{i}}} P D D_{i}{ }^{-\sigma_{T_{i}}}\left[\left(\gamma^{T_{i}}\right)^{\sigma_{T_{i}}} P E_{i}^{1-\sigma_{T_{i}}}+\left(1-\gamma^{T_{i}}\right)^{\sigma_{T_{i}}} P D D_{i}{ }^{1-\sigma_{T_{i}}}\right]^{\left.\frac{\sigma_{T_{i}}}{\left(1-\sigma_{T_{i}}\right.}\right)}\right. \\
& E_{i}=\left(\frac{X D_{i}}{a T_{i}}\right)\left\{\left(\gamma^{T_{i}}\right)^{\sigma_{T_{i}}} P E_{i}{ }^{-\sigma_{T_{i}}}\left[\left(\gamma^{T_{i}}\right)^{\sigma_{T_{i}}} P E_{i}{ }^{1-\sigma_{T_{i}}}+\left(1-\gamma^{T_{i}}\right)^{\sigma_{T_{i}}} P D D_{i}^{1-\sigma_{T_{i}}}\right]^{\frac{\sigma_{T_{i}}}{\left(1-\sigma_{T_{i}}\right)}}\right\}
\end{aligned}
$$

Condition of zero profits is given by:

$$
P D_{i}=\left(P E_{i} E_{i}+P D D_{i} X D D_{i}\right) / X D_{i}
$$

Equation (55) determines price of domestic goods $\left(P D_{i}\right)$. According to the Armington assumption producers choose combination of domestic $\left(X D D_{i}\right)$ and foreign variation of a goods $\left(M_{i}\right)$ to produce final/composite good $\left(X_{i}\right)$. To find the optimal combination producers maximize final goods sales revenues at price $P_{i}$, subject to CES production function:

$$
\max P_{i} X_{i}=P M_{i} M_{i}+P D D_{i} X D D_{i}
$$

Subject to:

$$
X_{i}=a A_{i}\left(\gamma_{A_{i}} M_{i}^{-\rho_{A_{i}}}+\left(1-\gamma_{A_{i}}\right) X D D_{i}^{-\rho_{A_{i}}}\right)^{-1 / \rho_{A_{i}}}
$$

where $P D D_{i}$ represents the prices of domestic goods supplied to the domestic market, while $\sigma_{A_{i}}=1 /\left(1+\rho_{A_{i}}\right)$ represents elasticity of substitution. $a A_{i}$ is a shift parameter of the CES function. Solution of the problem generates demand functions for imports and final goods $\left(X_{i}\right)$ :

$$
\begin{aligned}
& X_{i}=\frac{a A_{i} X D D_{i}}{\left\{\left(1-\gamma^{A_{i}}\right)^{\sigma_{A_{i}}} P D D_{i}{ }^{-\sigma_{A_{i}}}\left[\left(\gamma^{A_{i}}\right)^{\sigma_{A_{i}}} P M_{i}{ }^{1-\sigma_{A_{i}}}+\left(1-\gamma^{A_{i}}\right)^{\sigma_{A_{i}}} P D D_{i}{ }^{1-\sigma_{A_{i}}}\right]^{\left.\frac{\sigma_{A_{i}}}{1-\sigma_{A_{i}}}\right)}\right\}} \\
& M_{i}=\left(\frac{X_{i}}{a A_{i}}\right)\left\{\left(\gamma^{A_{i}}\right)^{\sigma_{A_{i}}} P M^{-\sigma_{A_{i}}}\left[\left(\gamma^{A_{i}}\right)^{\sigma_{A_{i}}} P M_{i}^{1-\sigma_{A_{i}}}+\left(1-\gamma^{A_{i}}\right)^{\sigma_{A_{i}}} P D D_{i}{ }^{1-\sigma_{A_{i}}}\right]^{\left.\frac{\sigma_{A_{i}}}{\left(1-\sigma_{A_{i}}\right.}\right)}\right.
\end{aligned}
$$

Condition of zero profits is given by:

$$
P D D_{i}=\left(X_{i} P_{i}-P M_{i} M_{i}\right) / X D D_{i}
$$

Condition (60) determines the price of domestic goods in domestic market $\left(P D D_{i}\right)$. Balance of payments equilibrium condition with exogenous foreign savings determines equilibrium exchange rate: 


$$
S_{F}=\sum_{i=1}^{7} P M_{i} M_{i}-\sum_{i=1}^{7} P \mathrm{E}_{i} E_{i}
$$

Even though the Croatian National Bank follows a policy of stable exchange rate to the Euro, the model assumes flexible exchange rate regime. The reason to do this is a warning by experts in CGE modeling. They argue that fixed exchange rate regime needs solid empirical foundation to be implemented (e.g. Gilbert and Tower 2013). By assuming fixed exchange rate perfect availability of foreign savings in a domestic economy is assumed. In a model for Croatia such assumption would be unrealistic. This view is supported by the recent crisis where Croatia experienced depreciation pressures due to the sharp decline in foreign investment inflows (Globan 2012, 2015).

\section{Labor market}

Two assumptions are related to the labor market. Firstly, model tries to replicate Croatian reality by assuming unemployment in equilibrium. Inclusion of this assumption enables us to shed some light on effects of labor market disequilibrium for classical theoretical conclusions on economic effects of environmental policies in agriculture.

The second assumption relates to assumed immobility of agricultural labor. According to Acar (2003), unlike the ideal world and neoclassical description of markets where labor is perfectly mobile among sectors and responds quickly to wage differential, in reality we can witness large frictions in the labor markets which unfavorably influence labor mobility among sectors. The authors stress that the assumption of perfect labor mobility is especially questionable in case of lower skilled labor as it is the case in agriculture.

\section{Unemployment}

In the model the general equilibrium is attainable with unutilized labor resources (with unemployment), and is given by:

$$
\sum_{i=1}^{7} L_{i}+U_{N}=L_{S}
$$

In line with (62) total available (fixed) supply of labor in an economy $\left(L_{S}\right)$ is not equal to total demand for labor $\left(\sum_{i=1}^{7} L_{i}\right)$, and difference between supply and demand for labor determines unemployment $\left(U_{N}\right)$. In the benchmark model it is assumed that unemployment in the market is generated according to the following equation:

$$
\left[\left(P_{L}{ }^{1} / C P I^{1}\right) /\left(P_{L}^{0} / C P I^{0}\right)-1\right]=\operatorname{Phillips}\left[\left(U_{N}{ }^{1} / L_{s}{ }^{1}\right) /\left(U_{N}{ }^{0} / L_{s}{ }^{0}\right)-1\right.
$$

Where Phillips represents the negative effect of the unemployment rate $\left(U_{N}\right)$ on consumer price index $(C P I)$, and it has characteristic negative sign. Equation (63) is different from the Phillips relation, and it determines the unemployment rate but not the inflation rate. In a CGE model the price level is determined exogenously according to (42). Thus, by using such modified Phillips curve type schedule we determine unemployment rate where we assume the relative changes in price of labor compared to changes of consumer prices influence the decision of consumers regarding their labor 
supply. Due to issues with proving such relationship in Croatia, results of the benchmark model were tested with assumption on existence of the wage curve according to Cardenete et al. (2012). The results show robustness of the benchmark model based on assumption (63). However, it should be noted that Botrić and Nestić (2008) point to weakness (and in some cases non-existence) of wage curve mechanism in Croatia.

\section{Agricultural Labor Mobility}

We assume that agricultural labor is sector specific and thus immobile among sectors. One way to model imperfect mobility of agricultural labor could be based on HarrisTodaro assumptions (Gilbert and Wahl 2002). However, due to the clarity of conclusion this paper assumes complete immobility of agricultural labor. In this way we generate a model with specific production factors (Gilbert and Tower 2013). Thus, the equation (62) is modified to:

$$
\begin{aligned}
& \sum_{n i=1}^{6} L_{n i}+L_{A}=\overline{L_{S}}-U_{N} \\
& L_{A}=\bar{L}_{A}
\end{aligned}
$$

Equations (64) and (65) imply that labor is compensated differently in agricultural and other sectors. Sectoral wages depend on its marginal products. Therefore, the model uses two labor prices- $P_{L} \forall i \neq A$ and $P_{L A}$ for $i=A$.

\section{Equilibrium}

To solve the model defined by previously presented equations it is necessary to fix certain variables. Currently the model has fewer equations than variables (A.170: A.178). Thus, it is necessary to exogenously fix eight variables. We fix the following variables:

$$
\begin{aligned}
& \sum_{i=1}^{7} K_{i}=K_{S} \\
& \sum_{n i=1}^{6} L_{n i}+L_{A}=\overline{L_{S}}-U_{N} \\
& \sum_{i=1}^{7} Z_{i}=Z_{S} \\
& T R O=\overline{T R O} \\
& S_{G}=\overline{S_{G}} \\
& S_{F}=\overline{S_{F}} \\
& L_{A}=\overline{L_{A}} \\
& P_{L}=\overline{P_{L}}
\end{aligned}
$$

Equations (66)-(73) determine equilibrium values of variables: i) $P_{L}$, ii) $P_{K}$, iii) $P_{Z}$, iv) $T R O$, v) $S_{G}$, vi) $S_{F}$ and vii) $P_{L}$. Two out of seven equations determine $P_{L}$. Given that 
CGE models needs a numéraire price, it is necessary to exclude price setting equation from the labor market model. Thus, condition (73) demands exclusion of (67).

In equilibrium demand and supply of composite (final) goods should be equal, i.e.:

$$
X_{i}=C_{i}+I D_{i}+C G_{i}+\sum_{n i=1}^{6} i o_{i, n i} X D_{n i}+\left(\sum_{i=1}^{7} B_{i=B C}\right)
$$

Equation (74) determines equilibrium price in the goods market $\left(P_{i}\right)$.

\section{Abbreviations}

CAP: Common agricultural policy; CES: Constant elasticity of substitution; CET: Constant elasticity of transformation; CGE: Computable general equilibrium; CPA: Statistical classification of products by activity; EU: European union; GNB: Gross nitrogen balance; GTAP: Global trade analysis project; NUE: Nitrogen use efficiency; NVZs: Nitrate vulnerable zones; SAMs: Social accounting matrices; UAA: Utilized agricultural area

\section{Acknowledgements}

Not applicable.

\section{Authors' contributions}

ONJ has made substantial contributions to conception and design, acquisition of data, analysis and interpretation of data. JS has been involved in drafting the manuscript and revising it critically for important intellectual content. He has given final approval of the version to be submitted. Both authors read and approved the final manuscript.

\section{Funding}

This work has been supported in part by Croatian Science Foundation under the projects 7031 and 6785 . The funds were used for GAMS license purchase and renewal (License no. DC11328).

\section{Availability of data and materials}

All data generated or analyzed during this study are included in this published article [and its supplementary information files] or are available in the Eurostat Database, [https://ec.europa.eu/eurostat/data/database] in the cited Tables (see references).

\section{Competing interests}

The authors declare that they have no competing interests.

Received: 21 December 2018 Accepted: 16 January 2020

Published online: 13 February 2020

\section{References}

Acar M (2003) Agricultural unskilled labor mobility: does it matter? J Econ Integr 18:164-187

Blanchflower DG (2001) Unemployment, well-being, and wage curves in eastern and Central Europe. J Jpn Int Econ 15:364402. https://doi.org/10.1006/jjie.2001.0485

Botrić V (2012) NAIRU estimates for Croatia. Zb Rad Ekon Fak U Rijeci Časopis Za Ekon Teor Praksu 30:163-180

Botrić V, Nestić D (2008) Gender dimension of wage curves in transition: Croatian experience. In: Čičić M (ed) Transitional challenges of EU integration and globalization. Ekonomski fakultet Sarajevo, Sarajevo, pp 204-206

Brink C, van Grinsven HJM, Jacobsen BH, Klimont Z (2011) Costs and benefits of nitrogen in the environment. In: Sutton MA, Howard CM, Erisman JE (eds) The European nitrogen assessment: sources, effects and policy perspectives. Cambridge University Press, Cambridge

Burfisher ME (2011) Introduction to Computable General Equilibrium Models, New York

Cardenete MA, Guerra A-I, Sancho F (2012) Applied general equilibrium: an introduction. Springer-Verlag, Berlin Heidelberg

Ciaian P, y Paloma SG (2011) The value of EU agricultural landscape. Institute for Prospective Technological Studies (Joint Research Centre), Seville

Conrad K (2001) Computable general equilibrium models in environmental and resource economics. Discussion Papers 601 Institut fuer Volkswirtschaftslehre und Statistik, Abteilung fuer Volkswirtschaftslehre, Universität Mannheim, Mannheim

Croatian Bureau of Statistics (CBS) (2010) Prosječne mjesečne isplaćene neto plaće zaposlenih za prosinac 2010. Croatian Bureau of Statistics, Zagreb

Croatian Bureau of Statistics (CBS) (2011a) Anketa o potrošnji kućanstva - Osnovne karakteristike potrošnje i primanja kućanstava u 2010. Croatian Bureau of Statistics, Zagreb

Croatian Bureau of Statistics (CBS) (2011b) Anketa o radnoj snazi - aktivno stanovništvo u Republici Hrvatskoj 2010. - prosjek godine. Croatian Bureau of Statistics, Zagreb

Croatian Bureau of Statistics (CBS) (2015) Tablice ponude i uporabe i input-output tablica za 2010. Croatian Bureau of Statistics, Zagreb

Croatian Employment Service (2011) Izvješće o radu. Croatian Employment Service, Zagreb

Dise NB, Matzner E, Gundersen P (1998) Synthesis of nitrogen pools and fluxes from European Forest ecosystems. Water Air Soil Poll 105(1):143-154. https://doi.org/10.1023/A:1005068501864

Družić I, Tica J, Mamić A (2006) The challenge of application of Phillips curve: the case of Croatia. Zagreb Int Rev Econ Bus SCl:45-59. https://hrcak.srce.hr/index.php?show=toc\&id_broj=6349

EcoMod (2015) Energy and environmental CGE modeling with GAMS. EcoMod Modeling School, Prague 
European Environment Agency (2006) EEA report 1/2006 - Using the market for cost-effective environmental policy. https:// www.eea.europa.eu/publications/eea_report_2006_1. Accessed 9 Jul 2018

European Parliament and European Council (2000) Directive 2000/60/EC of the European Parliament and of the Council of 23 October 2000 establishing a framework for Community action in the field of water policy

Eurostat (2012) Statistics explained: Agri-environmental indicator - gross nitrogen balance. Eurostat, Bruxelles

Eurostat (2016) Agri-environmental indicators, Pressures and risks - Gross Nutrient Balance

Eurostat (2018a) Environmental taxes by economic activity (NACE Rev. 2)

Eurostat (2018b) Agri-environmental indicators, Pressures and risks - Gross Nutrient Balance

Eurostat (2019) Gross value added and income by $A^{*} 10$ industry breakdowns

FINA (2015) Agregirani podaci financijskih izvještaja poduzeća prema NKD. Financial Agency, Zagreb

Freire-González J (2018) Environmental taxation and the double dividend hypothesis in CGE modelling literature: a critical review. J Policy Modeling 40:194-223. https://doi.org/10.1016/j.jpolmod.2017.11.002

Galloway JN, Dentener FJ, Capone DG et al (2004) Nitrogen cycles: past, present, and future. Biogeochemistry 70:153-226. https://doi.org/10.1007/s10533-004-0370-0

Gilbert J, Tower E (2013) An introduction to numerical simulation for trade theory and policy. World Scientific Publishing Company, New Jersey. https://doi.org/10.1142/8414

Gilbert J, Wahl T (2002) Applied general equilibrium assessments of trade Libereralisation in China. World Econ 25:697-731. https://doi.org/10.1111/1467-9701.00458

Globan T (2012) Capital flow reversals during a financial crisis: does the pre-crisis composition matter? Ekon Pregl 63:587-607

Globan T (2015) From financial integration to sudden stops? New Evidence from EU transition countries. Czech J Econ Finance Finance Uver 65:336-359

Gunter S, Riera-Crichton D, Vegh C, Vuletin G (2018) Non-linear effects of tax changes on output: the role of the initial level of taxation. WB Policy Research WP No. 8668 December 2018, pp 1-48

Hertel T, McDougall R, Narayanan B, Aguiar A (2014) GTAP 8 Data Base documentation - chapter 14 behavioral parameters. In: Center for Global Trade Analysis http://www.gtap.agecon.purdue.edu/resources/res_display.asp?RecordID=4551

Hosoe N, Gasawa K, Hashimoto H (2015) Textbook of computable general equilibrium modeling - programming and simulations. Palgrave Macmillan, UK

Kampas A, White B (2004) Administrative costs and instrument choice for stochastic non-point source pollutants. Environ Resour Econ 27:109-133. https://doi.org/10.1023/B:EARE.0000017275.44350.e5

Kristkova Z, Ratinger T (2013) Modelling the efficiency of Agri-environmental payments to Czech agriculture in a CGE framework incorporating public goods approach. AGRIS -Line Pap Econ Inform 5:59-71

Krznar I (2011) An analysis of the domestic inflation rate dynamics and the Phillips curve, CNB Work Pap W-31 November 2011, pp 1-36

Lankoski J, Lichtenberg E, Ollikainen M (2010) Agri-environmental program compliance in a heterogeneous landscape. Environ Resour Econ 47:1-22. https://doi.org/10.1007/s10640-010-9361-x

Lankoski J, Ollikainen M (1999) The environmental effectiveness of alternative Agri-environmental policy reforms: theoretical and empirical analysis. Agric Food Sci 8:321-331

Lankoski J, Ollikainen M (2003) Agri-environmental externalities: a framework for designing targeted policies. Eur Rev Agric Econ 30:51-75. https://doi.org/10.1093/erae/30.1.51

Millennium Ecosystem Assessment (2005) Ecosystems and human well-being: synthesis. Island Press, Washington, DC

Ministry of Finance (2010) Statistički prikaz: Mjesečni statistički prikaz Ministarstva financija. Ministry of Finance, Zagreb

Muhammad A, Seale JL, Meade B, Regmi A (2011) International evidence on food consumption patterns: an update using 2005 international comparison program data. TB-1929. U.S. Dept. of Agriculture, Econ. Res. Serv., Washington

Nganou J-P (2005) Estimation of the parameters of a linear expenditure system (LES) demand function for a small African economy. https://mpra.ub.uni-muenchen.de/31450/. Accessed 9 Jul 2018

OECD (2001) Multifunctionality: towards an analytical framework. Organization for Economic Development, Paris

OECD (2012) Design and implementation of Agri-environmental policies: are guidelines feasible? In: Evaluation of Agri-environmental Policies: Selected Methodological Issues and Case Studies. OECD Publishing, Paris. https://doi.org/10.1787/9789264179332-4-en

Oenema O, Velthof G-L, Yamulki S, Jarvis SC (1997) Nitrous Oxide Emissions from Grazed Grassland. Soil Use Manage 13:288295. https://doi.org/10.1111/j.1475-2743.1997.tb00600.x

Oenema O, Witzke HP, Klimont Z et al (2009) Integrated assessment of promising measures to decrease nitrogen losses from agriculture in EU-27. Agric Ecosyst Environ 133:280-288. https://doi.org/10.1016/j.agee.2009.04.025

Parry IWH (1997) Environmental taxes and quotas in the presence of distorting taxes in factor markets. Resour Energy Econ 19:203-220. https://doi.org/10.1016/S0928-7655(96)00012-7

Parry IWH (1999) Agricultural policies in the presence of distorting taxes. Am J Agric Econ 18(1):212-230

Peterson JM, Boisvert RN, De Gorter H (2002) Environmental policies for a multifunctional agricultural sector in open economies. Eur Rev Agric Econ 29:423-443. https://doi.org/10.1093/eurrag/29.4.423

Refsgaard JC, Thorsen M, Jensen JB, Kleeschulte S, Hansen S (1999) Large scale Modelling of groundwater contamination from nitrate leaching. J Hydrol 221(3-4):117-140. https://doi.org/10.1016/S0022-1694(99)00081-5

Rockström J, Steffen W, Noone K et al (2009) A safe operating space for humanity. Nature 461:472-475. https://doi.org/10. 1038/461472a

Science for Environment Policy (2013) Nitrogen pollution and the European environment - implications for air quality policy. European Commission Directorate-General Environment, Brussels

Šergo Z, Saftić D, Težak A (2012) Stability of Phillips curve: the case of Croatia. Econ Res - Ekon Istraživanja Special Issue:65-85

Taheripour F, Khanna M, Nelson CH (2008) Welfare impacts of alternative public policies for agricultural pollution control in an open economy: a general equilibrium framework. Am J Agric Econ 90:701-718

Vermersch D, Bonnieux F, Rainelli P (1993) Abatement of agricultural pollution and economic incentives: the case of intensive livestock farming in France. Environ Resour Econ 3:285-296. https://doi.org/10.1007/BF00313163

\section{Publisher's Note}

Springer Nature remains neutral with regard to jurisdictional claims in published maps and institutional affiliations. 